SETTLEMENT PATTERNS OF KOREAN IMMIGRANTS

IN THE TORONTO CENSUS METROPOLITAN AREA (CMA)

By

(Colin Chungshik Kang, BA, Hannam University, 1998)

A Major Research Paper
Presented to Ryerson University

in partial fulfillment of the requirements for the degree of

Master of Arts

in the Program of

Immigration and Settlement Studies

Toronto, Ontario, Canada, 2016

(C) Colin Chungshik Kang 2016 


\section{AUTHOR'S DECLARATION FOR ELECTRONIC SUBMISSION OF A MAJOR RESEARCH PAPER (MRP)}

I hereby declare that I am the sole author of this Major Research Paper. This is a true copy of the $\mathrm{MRP}$, including any required final revisions, as accepted by my examiners.

I authorize Ryerson University to lend this MRP to other institutions or individuals for the purpose of scholarly research.

I further authorize Ryerson University to reproduce this MRP by photocopying or by other means, in total or in part, at the request of other institutions or individuals for the purpose of scholarly research.

I understand that my MRP may be made electronically available to the public.

Colin Chungshik Kang 


\title{
Settlement Patterns of Korean Immigrants in the Toronto Census Metropolitan Area (CMA)
}

\author{
Colin Chungshik Kang \\ Master of Arts (2016) \\ Immigration and Settlement Studies \\ Ryerson University
}

\begin{abstract}
This paper focuses on settlement patterns of Korean immigrants in the Toronto Census Metropolitan Area (CMA) highlighting their high self-employment rate and active transnational activities. The objectives for the paper are to explore various causes of a high level of selfemployment rate among Korean immigrants, and to examine settlement patterns of Korean immigrants in the Toronto CMA by reviewing their immigration data, employment income and self-employment income data, residential locations, ethnic economy and human capital, and to understand how their active transnational activities combined with the factors listed above affected their settlement and integration experiences in Canada as they are inter-connected with various social and economic fabrics of the Korean community in the Toronto CMA.
\end{abstract}

Key words: Korean Ethnic Entrepreneurship, Self-employment, Ethnic Enclave, Social Exclusion and Transnationalism 


\section{Acknowledgements}

It has been an intense, but exciting learning experience for me on an academic and personal level throughout the program. I would like to reflect on the people who have supported and helped me in this journey. First of all, I would like to express my gratitude to my supervisor, Professor Shuguang Wang, for his support and inspiration. Your continuous motivation and valuable expertise have been very helpful throughout the process of writing my Major Research Paper. I would like to thank Professor Hare for taking time out from his busy schedule to serve as my second reader. I must also acknowledge my cohorts who shared their knowledge and experience throughout the program which inspired me to achieve more and made the learning experience more interesting and colourful.

I would also like to thank my parents for everlasting love and support. Thank you for always being there for me. Finally, my amazing partner, Dal! I know that I could not have done it without your love and support.

\section{Colin Chungshik Kang}

Toronto, August 23, 2016 


\section{Table of Contents}

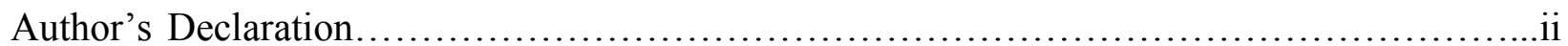

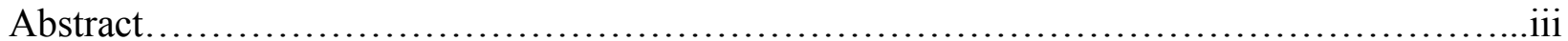

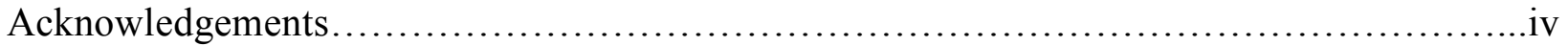

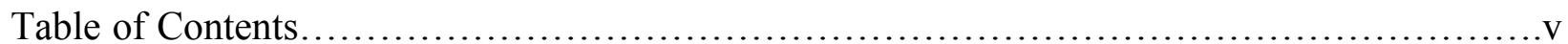

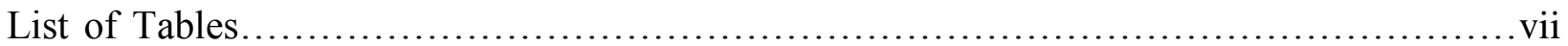

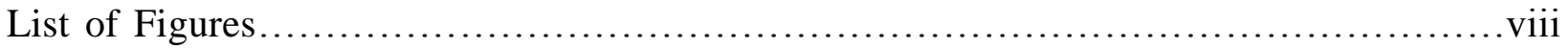

CHAPTER 1: INTRODUCTION .......................................................

CHAPTER 2: THE LITERATURE REVIEW .......................................... 6

2.1: Social Exclusion and High Self-employment rate, Ethnic Facilitation and Labour Market

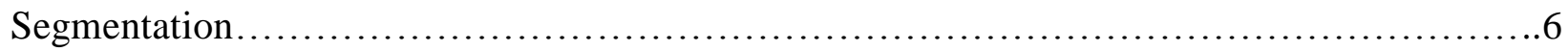

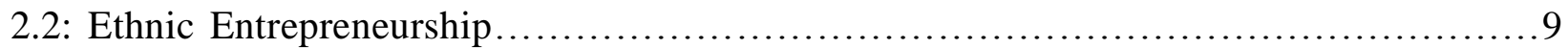

2.3: Settlement Patterns - Suburbanized Ethnic Enclaves and Transnational Communities......13

2.4: Transnational Activities, Economic Performances (of Self-employment) and Integration...16

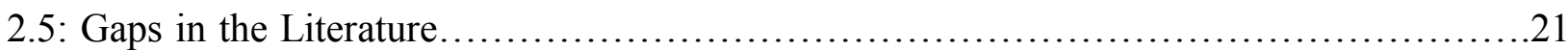

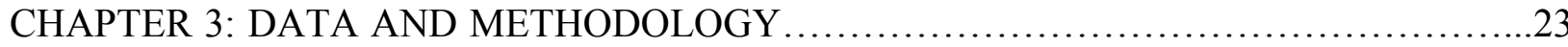

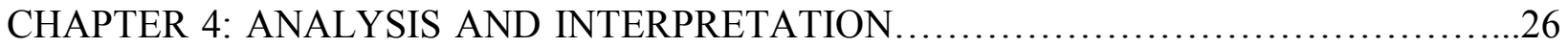

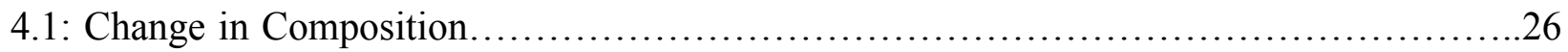

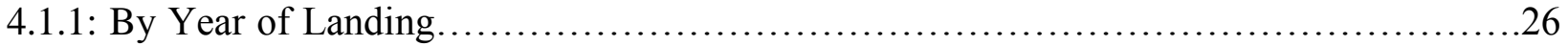




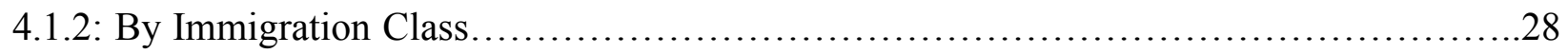

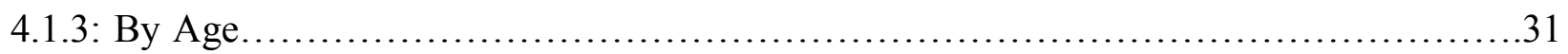

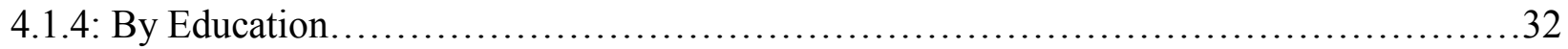

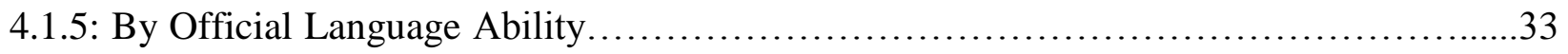

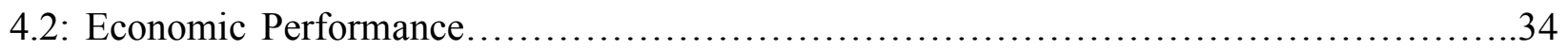

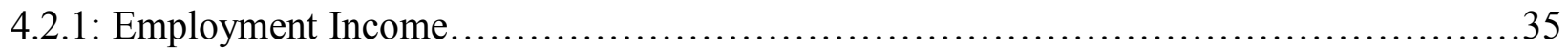

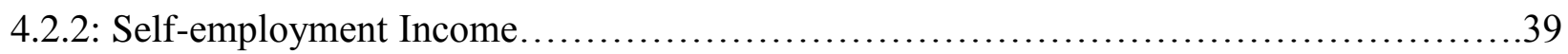

4.3: Settlement Patterns............................................................. 44

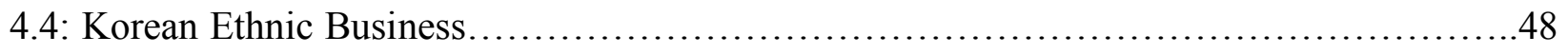

4.5: Case Study - Korean Supermarket Chains.........................................50

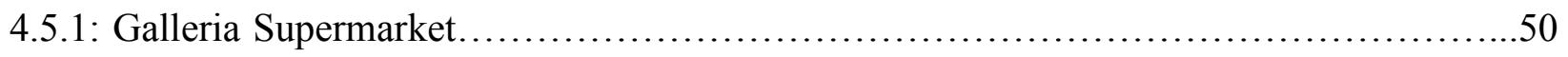

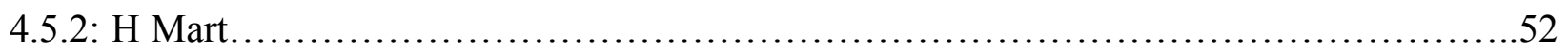

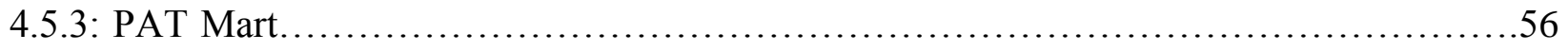

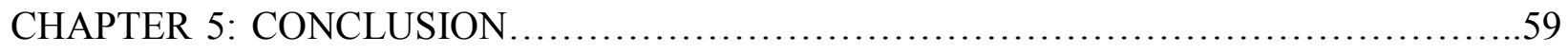

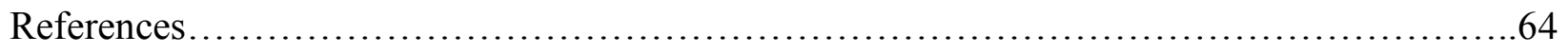




\section{List of Tables}

Table 2.1: Ethnic Economy VS. Ethnic Enclave Economy............................. 10

Table 4.1: Number of Korean Immigrants.........................................27

Table 4.2: Korean Immigrants in Canada by Immigration Category........................29

Table 4.3: Korean Immigrants in the Toronto CMA by Age Groups between 1980 and 2010... 32

Table 4.4: Educational Qualifications.............................................. 33

Table 4.5: Korean Adults (the Age between 20 and 55)' Canadian Language Ability...........34

Table 4.6: Average Employment Income by Racialized Group.............................35

Table 4.7: Average Employment Income for 2012 by Each Landed Year....................36

Table 4.8: Korean Immigrants' Employment Income by Immigration Category and Landing Year

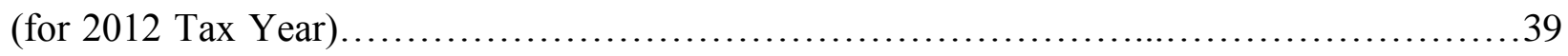

Table 4.9: Average Self-employment Income Chart in 2012 by Landing Year................40

Table 4.10: Self-employment Income in 2012, by Immigration Category and Landing Year.....43

Table 4.11: Major Korean Ethnic Businesses in the Toronto CMA.........................49 


\section{List of Figures}

Figure 4.1: Korean Immigrants in Canada by Immigration Category, 1998 and 2010.........30

Figure 4.2: Average Employment Income Chart..................................... 37

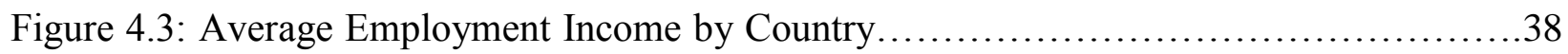

Figure 4.4: Average Self-employment Income Chart...................................41

Figure 4.5: Average Self-employment Income in 2012, by Country and Landing Year..........42

Figure 4.6: Settlement Pattern of Korean Immigrants in the Toronto CMA...................45

Figure 4.7: Geographical Distribution of Korean Businesses, Cultural and Religious Institutions

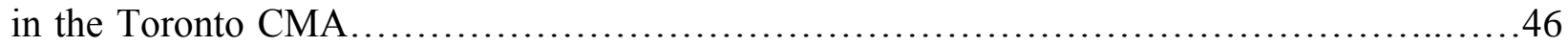

Figure 4.8: Inside of the Galleria Supermarket at York Mills and Don Mill...................52

Figure 4.9: H Mart in Richmond Hill, Ontario...........................................55

Figure 4.10: PAT Mart on Bloor Street West Toronto, Ontario..............................56

Figure 4.11: Korean Supermarkets in the Toronto CMA....................................58 


\section{CHAPTER 1: INTRODUCTION}

The Koreans form one of the largest visible minority groups in Canada (Statistics Canada, 2011). Starting in the 1960s, a growing number of Koreans immigrated to Canada for better economic opportunities and a better future for their families under Canada's new Point System that eliminated discriminatory factors in the immigration selection system (Kelley and Trebilcock, 2010; Yoon, 2006). However, it was not until the early 1990s when the majority of the Korean immigrants came to Canada under the economic class. The Korean immigrants were among the major beneficiaries of Canada's non-discriminatory Point System, resulting in 60 percent of the Korean immigrants in Canada having entered the country in the 1990s (Statistics Canada, 2007). A large number of educated Korean skilled professionals immigrated to Canada between the late 1990s and early 2000s, as the severe financial crisis took place in South Korea in 1997. According to South Korea's Ministry of Foreign Affairs (2013), the number of people of Korean origin in Canada was 206,000 in 2013. Most Koreans have settled in Ontario and British Columbia and they are heavily concentrated in urban centres, particularly in the Toronto Census Metropolitan Area (CMA) and the Vancouver CMA (Statistics Canada, 2007). According to Statistics Canada, Toronto CMA's Korean population in 2011 was 61,300 and Korea was the $9^{\text {th }}$ largest source country in the Toronto CMA by country of last permanent residence between 1996 and 2010.

At the end of the Korean War, Korea was divided into two countries, which are technically still at war today. The division of the countries causes political and military tensions continuously in the Korean peninsula. In the meantime, South Korea experienced a fast economic growth in 1970s and 1980s under the military dictatorship, but democracy was sacrificed in the name of economic growth. These radical political situations motivated many 
South Koreans to immigrate to North America. Korea is also a very populated country with a small territory and little natural resources. With the disadvantaged environment, the Korean economy has been heavily relying on its human capital creating an extremely competitive society. Needless to say, the importance of education is vital in a country where the human capital dominates its economic growth and the competitive education system created an unhealthy educational environment causing a high rate of suicide and depression among Korean teenagers. Many Korean parents chose to immigrate to Canada to provide a better and more flexible education environment for their children. Children's education and well-being is the Korean families' main motivation to immigrate to English-speaking countries. A more recent major factor that motivated the exodus of Koreans to English-speaking countries (such as Canada, United States, Australia and New Zealand) was the financial crisis in the late 1997 that hit several Asian countries including Korea. Due to the financial crisis, many professionals lost their jobs, and Canada's good public education system, fairly equal social system, stable and growing economy, and clean natural environment attracted many Koreans to settle for better quality of life along with more open immigration policy compared to the United States, Australia and New Zealand. Historically, the United States had been the most popular destination for Koreans to immigrate among the English speaking countries. However, in the early 2000s, Canada received more Korean immigrants than the United States. Han and Ibbott (2005) argued that Canada's more open immigration policy and a favourable exchange rate against the Canadian currency were the main factors for Canada to receive more Korean immigrants than the United States. However, according to the Landed Immigrant Data, an unfavourable exchange rate against the Canadian dollar in the late 2000s did not discourage Koreans from immigrating to Canada. It seems that Canada's more open immigration policy with the Point System was the 
main reason to attract more Korean immigrants than U.S. For the first time in many years, the number of immigrants from Korea decreased in 2008 and this short lived decline was mainly due to tougher immigration rules set by the Conservative government as a result of Canada's economic recession. With the neoliberal approach, the previous Harper government's immigration policy was focusing on the official language proficiency and pre-arranged employment in Canada to maximize new-comers' fast economic integration without providing adequate settlement services for new immigrants such as the official language training and job training to assist their economic and cultural integration. While the desire to immigrate to Canada among Koreans remains high, due to Canada's new immigration policy emphasizing official language ability and Canadian work experience, it is predicted that fewer Koreans will be admitted as immigrants in the future.

According to Statistics Canada (2007), South Korea has become one of the top source countries for international students in Canada and a majority of them chose Toronto or Vancouver as their Canadian destination. Korean students have become one of the major driving forces for the Korean local economies in Vancouver and Toronto for more than two decades as many businesses were generated to provide catered services to Korean students such as student agencies, English language schools, Korean homestays and travel agencies within the Korean community. Korean international students play a major role not only as consumers of Korean ethnic businesses but also as transnational actors to connect the Korean community in Canada with the home country as they are frequent travelers of both countries (Kwak 2012). Active transnational activities among Korean international students and immigrants in Canada are very distinctive features of Koreans in Canada and this trend is closely tied with the formation of Korean ethnic enclaves along with a massive inflow of diverse skilled workers and 
entrepreneurs. A large number of well-educated skilled workers, entrepreneurs and investors have immigrated to Canada since the 1990's under the Point System and business class. They were expected to perform well economically and integrate into the mainstream society successfully as most of them entered Canada with either a high level of human capital or financial capital. However, the income data shows that Korean immigrants are one of the lowest income earners among immigrant groups and they tend to reside in their own ethnic enclaves rather than integrate into the mainstream society. It seems reasonable to suggest that a high level of self-employment rate and entrepreneurship among Koreans is a result of the "blocked mobility" (Light and Gold 2000).

Despite the growing number of Korean immigrants in Canada, there has not been much research conducted for these immigrants particularly in recent years. The purpose of this research is to examine the settlement experiences of Korean immigrants in the Toronto CMA. The current research focuses on the two most distinctive features of Korean immigrants: a high selfemployment rate and growing transnational activities. These two features are inter-connected with various social and economic layers of the Korean community. The research questions are, "What caused the high self-employment rate among the Korean immigrant group in the Toronto CMA and how active transnational activities and a high level of ethnic entrepreneurship impact the settlement patterns of the Korean immigrant group in the Toronto CMA?" Theories of Social Exclusion, Ethnic Facilitation combined with Labour Market Segmentation, Ethnic Entrepreneurship and Transnationalism are used as the main theoretical frameworks to explain the settlement patterns of Korean immigrants in the Toronto CMA. The Ethnoburb (ethnic suburb) model is also referenced to explain how the high self-employment rate in the Korean immigrant group and their active transnational activities affected the formation of the Korean 
Ethnic Enclave in the Toronto CMA. The Toronto CMA is selected as the study area because it has the largest Korean community in Canada with the longest immigration history. This study should be useful for the Korean community help them to integrate into the Canadian society more successfully while maintaining their cultural identity. 


\section{CHAPTER 2: THE LITERATURE REVIEW}

This research uses Social Exclusion and Ethnic Facilitation combined with Labour Market Segmentation as the main conceptual frameworks to explain settlement experiences of Korean immigrants in the Toronto CMA. Transnationalism and the Ethnoburb (ethnic suburb) model are also used to explain how a high level of ethnic entrepreneurship among the Korean immigrants and their active transnational activities affected the formation of the Korean ethnic enclave in the Toronto CMA.

\section{1: Social Exclusion and High Self-employment rate, Ethnic Facilitation and Labour Market Segmentation}

The Social Exclusion theory has been frequently applied to describe the settlement patterns of racialized immigrants (Galabuzi, 2006). Hou and Wang (2011) argued that ethnic enclave formation is often the result of various forms of social exclusion such as limited labour market opportunities for immigrants, discrimination by employers and systemic barriers and discrimination layered in the receiving society. Exclusion practices in the Canadian society and the labour market against racialized immigrants are closely linked to the creation of racial hierarchies that "determine the distribution of opportunity" (Galabuzi, 2006:61). Due to limited language ability and systemic racial discrimination, many highly educated and skilled immigrants turn to self-employment and/or ethnic enclave employment with, in many cases, downgraded economic mobility. Many highly skilled immigrants tend to use less established formal or informal ethnic networks to find employment opportunities when their foreign experience and credentials are not recognized by Canadian employers (Salaff et al. 2003). As 
Breton (2003) described, skilled immigrants turn to self-employment as "defensive structuring" because they face various barriers. Couton (2014) reconfirmed the existence of institutional discrimination by pointing out that states and other political forces play major roles to not only interfere with resource allocation but often also control it within the political economy and statecentric models.

The Korean population in Canada has become well known for its high level of selfemployment, mainly family business arrangements (Lindsay, 2007). In fact, the self-employment rate of Korean immigrants in Canada is higher than 30 percent compared to only 15 percent for the general Canadians population. Koreans have the highest self-employment rate among all ethnic groups, with a 10 percent margin from the second highest ethnic group. However, Korean entrepreneurship is mainly small-scale retail and family businesses with low incomes. Couton (2014:10) argued that "Korean entrepreneurship in Canada appears to be more a defensive strategy than a path to successful economic integration”. Couton's argument is in line with the Social Exclusion Theory. Due to the institutional barriers imposed against racialized immigrants, such as discounting foreign work experience and not recognizing foreign credentials, many highly educated Korean immigrants had a high level of difficulty integrating into the Canadian labour market and became self-employed (Chan and Fong 2012).

Canadian employers' unwillingness to recognize foreign credentials and experience, and the limited language ability of many new immigrants, are the major obstacles to overcome for successful settlement in Canada (Schellenberg, G. and Maheux, H., 2007). It is also one of the systemic social exclusion practices that new immigrants face in their host countries in the process of settlement. Despite their high education level, many Korean immigrants came to Canada with limited English/French language skills, which led them to settle in their own ethnic 
enclave and engage in self-employment. In fact, the self- employed Koreans are less likely to use the Canadian official languages at work, indicating that they are more likely to work in an ethnic economy (Chan and Fong 2012). As Boyd and Alboim (2012) pointed out, the underutilization of immigrant talents is also linked to re- accreditation or re-certification to practise in their professions in Canada. The re- accreditation process in Canada is often found lengthy and complicated which, in many cases, forces immigrants to take low-paying jobs that are not related to their professional training.

As Couton (2014) argued, the Korean ethnic economy with high self-employment rate is a rather defensive strategy to survive, but the ethnic economy provides opportunities for new immigrants through collective actions by developing market niches (Waldinger et al. 1990). In their study of the Los Angeles Korean community, Light and Bonacich (1988) found that minority entrepreneurs typically hired employees from their own ethnic community and these employees received necessary training while working, which enabled them to establish their own businesses later on and often compete with their former employers. This cycle of ethnic economy is rather a defence strategy but provides a "training system" to new immigrants that the host country does not. However, Hiebert (2002) viewed this phenomenon in association with poor economic performance of ethnic entrepreneurship suggesting that through such a "training system", their already disadvantaged labour market is replicated in the experience of selfemployment. The Korean ethnic group's reported personal income was much lower than the average of Canadian-born individuals, and a much larger proportion of the Korean population falls below the low income cut-off level (Park, 2012; Lindsay, 2007). Korean immigrants came to Canada with either social, financial and/or human capital and they were expected to have a relatively smooth transition to the Canadian society and financially perform better than other 
ethnic groups that bring large number of refugees to Canada with little social, financial or human capital. However, the employment income tax data for Koreans do not reflect this expectation accordingly. According to Statistics Canada (2007), the average employment income of the Korean ethnic group was one of the lowest among all racialized ethnic groups. Korean employment income in 2006 was $\$ 30,474$ for men and \$21,112 for women; and these incomes were the second lowest among all racialized groups for both sexes. These data prove that Korean immigrants face social and economic exclusion in the Canadian society. The data also support Hiebert's (2002) argument that ethnic immigrants' labour market opportunities are further disadvantaged through ethnic entrepreneurship.

\section{2: Ethnic Entrepreneurship}

Ethnic entrepreneurship has a long history of development in immigrant receiving countries including Canada, but academic research around ethnic entrepreneurship is relatively new (Light and Gold, 2000; Wang et al. 2013). A recent trend of mixed economy in major immigrant receiving countries makes research more complicated. Ethnic entrepreneurship can be understood in two different forms: the ethnic economy and the ethnic enclave economy. While the former is originated from a theory of middleman minorities, the latter is associated with the labour market segmentation theory or the dual labour market theory, according to which disadvantaged immigrant groups are channelled into an undesirable and, secondary labour market, resulting in low income (Light and Gold, 2000). In addition, the ethnic enclave economy is associated with spatial concentration and co-ethnic customers/clients (Zhuang, Henandez and Wang, 2015). Ethnic entrepreneurship includes three major actors: co-ethnic self-employed, employers, and co-ethnic employees. According to Light and Gold (2000), Portes is the first 
researcher to include self-employed as part of the ethnic enclave economy. Before Portes, selfemployment was ignored and underestimated by social scientists. In fact, the presence of selfemployment in ethnic enclave economies has been much stronger than in the mainstream economy (Light and Gold, 2000). Therefore, it is logical to include self-employed as a major actor in the ethnic enclave economy, as their role can be significant for some ethnic groups that have a high ratio of self-employment rates.

Table 2.1: Ethnic Economy VS. Ethnic Enclave Economy

\begin{tabular}{|c|c|c|}
\hline & Ethnic Economy & Ethnic Enclave Economy \\
\hline \multirow{2}{*}{ Similarities } & \multicolumn{2}{|c|}{ Involving co-ethnic self-employed, employers and co-ethnic employees } \\
\hline & \multicolumn{2}{|c|}{ Immigrant(s) or ethnic group has a controlling ownership } \\
\hline \multirow{3}{*}{ Differences } & $\begin{array}{l}\text { No Spatial concentration of co-ethnic } \\
\text { businesses }\end{array}$ & Spatial clustering of co-ethnic businesses \\
\hline & $\begin{array}{l}\text { Derived mainly from the middleman } \\
\text { minorities }\end{array}$ & $\begin{array}{l}\text { Derived from dual market theory (labour } \\
\text { market segmentation) }\end{array}$ \\
\hline & $\begin{array}{l}\text { More common than ethnic enclave } \\
\text { business }\end{array}$ & Less common than ethnic business \\
\hline
\end{tabular}

(Source: Light and Gold, 2000)

Empirical research reveals that a high self-employment rate among immigrant groups is much greater than that of the mainstream population due to discrimination in the mainstream labour market, immigrants' limited language ability, and the depreciation of their human capital (Mata and Pendakur, 1999). The high self-employment rate among Korean immigrants in Canada can be explained as their defensive and survival strategy to cope with disadvantages associated with the blocked mobility as Zhou (2004) argued in her study of Korean ethnic entrepreneurship in Los Angeles. The dominant Korean business centre in the neighbourhood certainly serves not only as an economic hub for local Korean immigrants but also as a cultural and social Korean community centre. Zhou (2004:21) argued that Korean entrepreneurs in non- 
Korean neighbourhoods "do not tend to invest in the social structures of the neighbourhoods" whereas Korean entrepreneurs in Koreatown "have a stake in the community and are intertwined in multiple social relationships with co-ethnic residents and multiple ethnic social structures there." Through their collective co-ethnic efforts in their ethnic community, the Koreans protect themselves from further discrimination and disadvantages and move themselves up in society in general by investing in their ethnic community (Zhou, 2004).

Ethnic entrepreneurship in general create various benefits to urban economies of the receiving societies by providing a mechanism for immigrants' labour integration and investment for business opportunities as ethnic entrepreneurship has formed in the major urban areas (Zhuang, Henandez and Wang, 2015). While ethnic entrepreneurship creates employment opportunities for immigrants, the wages are usually much lower than those in the general labour market. It is reasonable to assume that ethnic employees are exploited and ethnic employers are the only beneficiaries in the ethnic entrepreneurship based on wage gaps between the general labour market and ethnic economies/ethnic enclave economies, but this assumption disregards different productivity levels among different ethnic employees (Light and Gold, 2000). However, as Light and Gold (2000) pointed out, the low wages in ethnic economies/ ethnic enclave economies can be only justified if the productivity level of all ethnic employees is lower than that of the mainstream labour market. It is a well-known factor that with Canada's immigration policy emphasizing human capital and favouring business class programs since the 1960s, many highly educated and high skilled racialized immigrants have entered Canada (Zhung, Hernandez and Wang, 2015) and many of them turned to their own ethnic economies/ ethnic enclave economies to find a job as they experience various systemic barriers. Considering this fact, it is hard to believe that the productivity level of ethnic employees is much lower than 
that of the mainstream labour forces. On the other hand, the ethnic entrepreneurship provides employment opportunities for co-ethnic immigrants, whereas the general labour market does not and jobs in the ethnic economies exist with a condition of the low wages (Light and Gold, 2000).

Another controversial topic around ethnic entrepreneurship is co-ethnic staffing. As stated before in this paper, ethnic entrepreneurship creates employment opportunities for coethnic immigrants, however, this co-ethnic staffing practice has generated some negative public opinions towards ethnic economies and created divisions among ethnic groups as well as between ethnic groups and the mainstream society. While some see co-ethnic staffing as a discriminatory hiring practice, others consider strategic ethnic solidarity between employees and employers for their own benefits (Light and Gold, 2000). There are also others who view it as a strictly business oriented decision to meet consumer demands by providing services in the same native language with a great degree of cultural understanding (Light and Gold 2000).

Traditionally, ethnic entrepreneurship was typically found in poor ethnic neighbourhoods or ghettos in urban centres where entrepreneurs established their business niches. In recent years, however, it has become more common to see that ethnic businesses opened up in more affluent urban areas and suburbs (Zhou, 2004). And some ethnic enclaves have become multiethnic neighbourhoods in the major North American cities such as North York in the Toronto CMA where many Korean, Chinese and Iranian immigrants reside. While the presence of the ethnic enclave economy is strong in the major Canadian urban centres such as the Toronto CMA, definition of ethnic entrepreneurship has become more ambiguous as some major mainstream industries enter the profitable ethnic markets by channeling each ethnic culture and some ethnic businesses become mainstream by attracting diverse group of people (Zhuang, Hernandez and Wang, 2015). Recently, some immigrants and ethnic groups have successfully incorporated their 
ethnic specialties and distinctiveness into the mainstream businesses (Zhou, 2004) and a few major Korean supermarket chains in the Toronto CMA such as Galleria and H Mart have made great efforts to become the major ethnic supermarket chains that appeal to different ethnic groups and even to the mainstream society after witnessing the success of T\&T (Chinese ethnic supermarket chain now owned by the mainstream grocery giant Loblaws).

\section{3: Settlement Patterns - Suburbanized Ethnic Enclaves and Transnational}

\section{Communities}

It was the Chicago school sociologists who initiated the study of immigrant settlement patterns in the early 1920s. According to them, new immigrants with little economic and social capital used to typically settle in impoverished inner-city areas but eventually moved out to the suburbs after attaining upward economic mobility (Ghosh and Garrison, 2015). However, the Chicago School failed to provide a rationale behind ethnic concentration in certain areas. Massey (1985) later elaborated the study of the Chicago school by developing a spatial assimilation model. According to his model, immigrants tend to live close to their own ethnic groups with similar economic backgrounds- resulting in traditional inner city ethnic enclaves detached from the mainstream society and they eventually achieve spatial assimilation after attaining economic and cultural assimilation by settling in the mainstream area from ethnic enclaves (Ghosh and Garrison, 2015). Therefore, Massey regarded ethnic enclaves as temporary and transitory places in the process of assimilation (Ghosh and Garrison, 2015). Traditionally, spatial concentration of a certain ethnic group was perceived as a lack of integration to the mainstream society resulted from social exclusion, but new suburban ethnic enclaves in major North American cities are rather voluntary and their higher social and economic status creates affluent middle class ethnic 
neighbourhoods in the suburbs. These voluntarily segregated ethnic enclaves not only thrive economically and culturally but also, gain bigger political power as unified ethnic groups (Siemiatycki and Matheson 2005).

The change of Canadian immigration policy to emphasize human capital and favour business class immigrants since the 1960s have enabled a large inflow of racialized immigrants, and their spatial concentration in major urban areas along with their hyper transnational identities have created expansive ethnic business areas in Canada's major cities (Zhuang, Hernandez and Wang, 2015). With Canada's multiculturalism policy, many ethnic enclaves have been formed in larger Canadian cities such as Vancouver, Montreal and Toronto, and it is evident in recent decades that ethnic enclaves have been shifted from segregated and crowded inner-city ghettos to spacious suburbs as more economic immigrants with empowered human and financial capitals were brought to Canada. Immigrants used to settle in the inner city of the major CMAs but the immigration settlement pattern in the Toronto CMA has shifted from the traditional inner city to the suburbs (Murdie and Teixeira, 2003). New immigrants with professional backgrounds and (or) financial ability have been able to directly settle in the suburbs, who prefer to settle in more spacious and less crowded environments without living in a ghetto in the city where most immigrants used to settle. Brampton and Markham are two typical examples of suburbanized ethnic enclaves in the Toronto CMA representing South Asian and Chinese ethnic groups respectively. While Canada's multiculturalism policy has promoted diverse ethnic enclaves, it can also be argued that ethnic enclaves are not products of multiculturalism but a survival strategy from social exclusion.

Li (1997) proposed a new model of ethnic settlement called "ethnoburb (ethnic suburb)" and defined it as suburban ethnic clusters of residential areas and business districts in large 
metropolitan areas. However, Li's ethnoburb model is generally multiethnic which is contradictory to the case of Brampton and Markham where one ethnic group dominates the population in the city. $\mathrm{Li}$ (1997) argued that one ethnic group does not necessarily comprise majority to form an enthnoburb but has significant concentration with a relatively self-sustaining ethnic economy and a high degree of institutional completeness in the area. While Li's ethnoburb model requires clearer definitions of specific variables (Wang and Zhong, 2013), her ethnoburb model seems more suitable for mid- or small-sized ethnic groups to examine their settlement patterns. The Korean ethnic group in the Toronto CMA is relatively small compared to other major racialized groups. However, it would be interesting to find out whether the Koreans have followed the suburbanized residential trends that are found with other major racialized ethnic groups such as South Asians or Chinese in the Toronto CMA. Li (1997) also pointed out that the ethnoburb is formed as an urban ethnic community with extensive external connections and plays a major role as a global outpost as a result of economic globalisation and geopolitical shifts. Li (1997) viewed the ethnoburb as a global outpost rather than the segregated ethnic enclave from the main society. Residential clusters and ethnic enclaves are closely tied with immigrants' transnational activities. Contrary to the traditional impoverished inner-city ethnic enclaves, affluent ethnic enclaves in the suburbs (also called "ethnic communities") have formed as diverse and educated immigrants "enter the city with disparate human and financial capital" and these ethnic communities are formed based on a permanent basis (Ghosh and Garrison, 2015:396). 


\section{4: Transnational Activities, Economic Performances (of Self-employment) and Integration}

Since the late $19^{\text {th }}$ century, many immigrants have maintained political, social and economic relationships with their home countries. Even though transnationalism is not a new phenomenon, its theory associated with migration was initially conceptualized by Linda Basch and her collaborators in the early 1990s (Wong and Satzewich, 2006). They defined transnationalism as "the process by which immigrants forge and sustain multi-stranded social relations that link together their societies of origin and settlement. They call these processes transnationalism to emphasize that many immigrants today build social fields that cross geographic, cultural, and political borders" (Basch, Glick-Schiller and Blanc-Szanton, 1994:6). In simple and concise terms, transnationalism can be understood as multiple ties and interactions linking people and institutions across the borders of nation states (Vertovec, 1999). As the scope of transnational activities can be very broad, its implications on migration and settlement studies are also extensive from macro level to daily micro transnational activities. Furthermore, the transnational concept expanded not only to people but also to various powerful actors, such as nation states, multinational corporations and international organizations.

Within the global neoliberalism context, the nation state's power is negotiated with transnational capital and powerful international organizations that dominate the flow of migration. Various economic, social and political ties of migrants in multiple places motivate people to move around and their transnational conditions reshape both the sending and receiving societies through the transnational process. Portes (1997:813) argued that "the construction of transnational communities by immigrants is a process driven by the very forces promoting economic globalization, as common people are caught in their web and learn to use new 
technologies". Transnationalism is also identified with two levels of institutionalization:

"transnationalism from above" and "transnationalism from below". Transnationalism from above represents the capitalist class and international elites, whose migration movement and activities are motivated by multinational corporations and other supranational organizations (Wong and Satzewich, 2006). Transnationalism from below is formed by non-elite groups and ordinary people whose activities are seen as a defensive strategy or resistance to dominant structures (Guarnizo, Landolt, and Portes, 1999). Transnational business activities of immigrant entrepreneurs could be a great example of transnationalism from below as they become entrepreneurs to avoid stagnant, low-wage and menial labour (Guarnizo, Landolt, and Portes, 1999). Transnationalism from below supports the social exclusion and labour market segmentation theory addressed in this paper. Some research reveals that transnational activities of immigrants are closely tied to their ethnic entrepreneurship and structural barriers attached to their immigrant status, and racial discrimination and exclusion are common elements of both transnational activities of immigrants and ethnic entrepreneurship (Zhou 2004). In addition, a recent massive inflow of highly educated skilled workers fueled active transnational activities among immigrants and many of them have become entrepreneurs as they can utilize their skillset, bicultural literacy, and transnational networks to generate higher income. Many transnational businesses are based in the host countries and immigrants involving transnational businesses experience upward mobility by using their transnational entrepreneurship (Zhou 2004).

Immigrants who typically keep strong ties with their home countries are often led to a marginalized status, because they are less integrated into the mainstream society. However, these immigrants can take a leadership role in the globalized modern society by creating cross-cultural environments (Yoon, 2012). Transnationalism can be defined as immigrants' encounters and 
experiences across more than one state boundary typically between their home country and a newly settled country. It seems that transnationalism is inevitable and rather necessary in this globalized world. Thus, immigrants' settlement process is more than pursuing a better life and their multi-layered connections between the receiving and sending countries make this process more complex involving their social, emotional, economic and political lives (Kelly, 2003).

As Simmons (2010) pointed out, international migrants are considered key transnational players connecting themselves and their adopted community to family members and friends in their home countries. With ongoing declines in transport and communication costs and continuous evolution of communication technologies (Diminescu, 2008; Panagakos and Horst, 2006) transnational activities among immigrants are greater than ever. Li (1997) considered ethnic enclaves in immigrant countries to be global outposts in the international economic system through immigrants' continuous transnational activities. It is fair to say that Li's argument supports that economic transnational activities aid integration of immigrants in their new country.

On the other hand, some writers suspect that transnationalism would weaken or slow down the integration processes of new immigrants in their new country of settlement. In other words, active transnational activities could interrupt local socialization and language learning and impede a sense of belonging in their new country. However, Kelly (2003) argued that transnational activities do not necessarily imply a lack of integration and it must be carefully modulated to acknowledge the diversity of experiences among and between immigrant groups as studies on each immigrant group have different outcomes. While Li (1997) focused on economic 
impacts of transnational activities, transnational activities themselves also involve various dimensions such as evolution of culture, politics and regime changing (Waldinger 2013).

Yoon (2012) argued that transnational phenomena appear prominently in many economic, social, and cultural domains of overseas Koreans today and human interchanges and the movement of capital between South Korea and the country of residence are increasing daily. He pointed out that the Korea town in Los Angeles is a great example to explain how transnational activities impacted not only local Korean ethnic economy and culture but also economic exchanges between the two countries. Some Korean families in the Toronto CMA often live separately, with some family members, usually fathers, remaining in Korea to keep their job or business to support their family in Canada, while the mothers and children living in Canada. These types of families are called "goose families". "The goose refers to the seasonal visits reuniting the separated families - the way geese migrate each year" and the term "goose family" was added to the Korean dictionary in 2004 as this type of family arrangement has become widespread (Chow 2012). The "goose family" trend can be seen as another defensive strategy for Korean immigrants to cope with the barriers they face in the Canadian society. The fathers are generally highly educated and most of them are either professionals or senior managers in Korea. However, their limited English ability and lack of recognition for their Korean credentials from Canadian employers block them from integrating into the Canadian labour market. The "goose families" also often face multiple layers of difficulties due to their separated family situation causing various family crises and leading to high levels of stress or even physical violence between family members in some cases (Chow, 2012). 
These goose families along with Korean international students in Canada play major roles in the transnational activities, because their family members live in both countries and continue to share strong bonds of collective welfare and unity (Huang and Yeoh 2005). Korea is one of the major source countries for international students in Canada, and Korean students are not only consumers of Canadian education but also mediators for and contributors to the production side of both education sector and local Korean ethnic economy (Kwak 2012). This large number of Korean students have become a driving force for the Korean local economies in Vancouver and Toronto for more than two decades. Many student-catered service businesses were generated, such as student agencies, English language schools, Korean homestays and travel agencies.

As transnational activities involve more than two different geographical territories, their impacts on each territory are interconnected and the impacts on each territory are uniquely formed within its own resources and environment. As Wong and Satzewich (2006: 2) put it in simple terms "transnationalism is a global phenomenon marked by local distinctions". It is fair to say that Canada's multiculturalism and dual citizenship policies have encouraged immigrants to engage in transnational activities. However, various structural barriers such as racial discrimination and language barriers that immigrants face in Canada also motivated immigrants' active transnational activities as a defensive settlement strategy. Formation of self-sustainable ethnic enclaves in Canada's major urban areas such as Toronto, Montreal and Vancouver can be understood within these organic relationships among various social, economic and political determinants of transnationalism. Transnational immigrants' active participation in economic, cultural and political events transforms a receiving city's urban setting. In a reciprocal way, immigrants' transnational activities are influenced by the urban setting, including a city's immigration history, patterns of residential segregation, labour-market segmentation, local 
political structures, local social institutions, and even predominant urban values. (Preston, Kobayashi, and Siemiatycki, 2006)

Active transnational activities among Koreans affected a business pattern of the local Korean economy in the Toronto CMA as the local Korean ethnic businesses in the Toronto CMA adapt new cultural trends from Korea faster to meet the demands from local Koreans including Korean international students. As a result, many Korean freight forwarding companies and trading companies which import trendy Korean items including food products, fashion items and cultural content products have been established. As Li (1998) pointed out, the continuous transnational activities among Koreans in the Toronto CMA and Korean immigrants' strong ties to the globalizing economy, revealing their role as outposts in the emerging international economic system contributed to the formation of the Korean "enthnoburb" in the Toronto CMA.

\section{5: Gaps in the Literature}

Most prominent studies of Korean immigrants in North America have been conducted in the U.S. While these studies can be very useful to understand the fundamental of Korean communities in North America in general, many differences exist between Koreans in two countries as government policies, economic climates and some other major factors that could influence settlement experiences are different between two countries. For this reason, it is important to build a bigger Canadian archive and there have been some more recent Canadian studies about Korean immigrants but, more Canadian studies are needed to better understand Koreans in Canada. 
While Hiebert (2002) and Kwak's (2012) papers provide extensive information on Korean immigrants in Canada by focusing on their ethnic entrepreneurship and transnational activities, these studies are either nation-wide or Vancouver-focused studies. In addition, these studies failed to offer a broad range of settlement experiences of Korean immigrants in Canada. The goal of this research paper is to provide a holistic viewpoint of more recent settlement experiences of Koreans in the Toronto CMA by highlighting their strong ethnic entrepreneurship in relation to a high self-employment rate among Koreans, active transnational activities, spatial settlement patterns and by connecting these segmented aspects of settlement experiences to better understand more recent settlement experiences of Korean immigrants in Canada. 


\section{Chapter 3: Data and Methodology}

The objectives for the research are to explore various causes of a high level of selfemployment rate and entrepreneurship among Korean immigrants, and to examine the formation of a Korean suburban Ethnic Enclave (Ethnic Suburb) in the Toronto CMA by examining their immigration experiences, residential locations, ethnic economy and human capital, in order to understand the impact of transnational activities in their settlement and integration experiences in Canada. The main research questions are, "What caused the high self-employment rate among the Korean immigrant group in the Toronto CMA and how active transnational activities and a high level of ethnic entrepreneurship impact the settlement patterns of the Korean immigrant group in the Toronto CMA?"

This research paper is primarily quantitative in nature. The literature review provides a premise for the argument and theoretical frameworks for the statistical analysis. This research uses four main data sources to examine a settlement pattern of the Korean ethnic group in the Toronto CMA. First, Landed Immigrant Data System (LIDS) from 1980 to 2010 were used to identify the Korean immigrants in the Toronto CMA by their year of landing, immigration class, education level, age and Canadian language ability. Second, the 2006s Canadian Census Data were used to find out where the Korean immigrants reside in the Toronto CMA. Third, some commercial, professional, educational and religious institution data in the Toronto CMA have been collected from the Korean business directory prepared by the Korea Times Daily Canada to analyze diversification and spatial patterns of Korean ethnic businesses and institutions in the Toronto CMA. The second and third data are used to examine the size and location of Korean population and the level of Korean ethnic business concentration in the Toronto CMA to examine the formation of a Korean "Ethnoburb" in the Toronto CMA. GIS (Geographic 
Information System) software is used to generate maps to provide visual assistance for better understanding of settlement patterns of Korean immigrants. Lastly, immigrants' Employment Income and Self-employment Income Data for year 2012 for each landing year from 1998 to 2012 from Statistics Canada 2015 (Tax Data in Landed Immigrant Data System) are used to analyze the Korean immigrants' economic performance and how their high self-employment rate affected their overall economic performance and settlement patterns. Their Employment Income and Self-employment Data are also analyzed with immigration categories to understand their economic performance. Some immigration categories such as refugees, humanitarian and compassionate grounds are not included in the study as numbers of Korean immigrants entering into Canada under these categories are very small. Various charts and tables are created to deliver exact values and findings effectively.

It should be pointed out that employment income data do not reflect entrepreneurs' income accurately, because they only provide personal income which does not include business incomes. Self-employment income is typically much lower than employment income because the self-employed are allowed to deduct their business expenses. As there are no official government collected data for the Korean ethnic businesses and institutions, the Korean business directory sourced from the Korea Times Daily Canada is used. As the data have been collected selectively from one private source, the accuracy of data is somewhat questionable. However, it can be said that the data used for this research are reasonably representative to understand the settlement patterns of Koreans in the Toronto CMA. In addition, some Canada-wide data such as the selfemployment rate among Koreans in Canada and employment income data for immigrants are used because no Toronto CMA data are available. As a result, some degree of generalization is necessary. 
Some qualitative methods may provide a sound base to support the statistical data or to explain differences if there is a gap between the literature and the statistical data but, using a small sample size would not be appropriate to make generalizations about the population at large. For this reason, this research focuses on quantitative analysis. Alternatively, content analysis could be an option to analyze settlement trends of the Korean immigrants in the Toronto CMA from the Canadian government policy's perspective with various government discourses as it provides evidence in a reliable and systematic manner (Trimble and Treiberg, 2011). 


\section{Chapter 4: Analysis and Interpretation}

\section{1: Changes in Composition:}

\subsection{1: By Year of Landing}

Statistics Canada (2011) reported that the Korean population was 61,300 in the Toronto CMA in 2011. This number represents approximately $1 \%$ of the total population in the area. According to the LIDS, a steady stream of Korean immigrants entered the Toronto CMA in the 1980s. The total number of Korean immigrants who came to the Toronto CMA in 1980 was 429 and the number doubled in 1989 to 881 . It was in the late 1990s that a sudden surge of Korean immigrants in the Toronto CMA occurred. As can be seen in Table 1, the number of Koreans who landed in the Toronto CMA in 1998 was 1,699, but it jumped to 2,998 in the following year. In 2001, a record high number of 4,698 new Korean immigrants found homes in the Toronto CMA. This big wave of Korean immigrants entering the Toronto CMA from 1998 to 2001 is linked to the financial crisis which was started in 1997 in Korea. Many professionals and business people came to the Toronto CMA for better economic opportunities. However, since 2001, the number of Korean immigrants landing in the Toronto CMA started to decrease until 2007. After that, the number started to increase again with the total number of newcomers at 2,634 in 2009.

The total number of Koreans who entered the Toronto CMA between 1980 and 2010 was 44,799, which represents $73 \%$ of the total Korean population in the Toronto CMA based on 2011 census. The total number of Koreans immigrated to Canada between 1980 and 2010 was 137,938 and this data shows that $32.48 \%$ of all Koreans chose the Toronto CMA as home. As shown in Table 4.1, while a large number of Koreans immigrated to Canada in the late 2000s, the ratio of Koreans settled in the Toronto CMA decreased significantly. I would argue that this new settlement trend is largely due to the more approachable provincial nominee programs. It seems that the Canadian government's strategy to encourage more new immigrants to settle in less desirable provinces to promote local economies by working with provincial governments and promoting more favourable provincial nominee programs worked well. 


\section{Table 4.1: Number of Korean Immigrants}

\begin{tabular}{|l|l|l|}
\hline & Canada & $\begin{array}{l}\text { Toronto } \\
\text { CMA }\end{array}$ \\
\hline 1980 & 956 & 429 \\
\hline 1981 & 1430 & 550 \\
\hline 1982 & 1507 & 686 \\
\hline 1983 & 1017 & 396 \\
\hline 1984 & 801 & 317 \\
\hline 1985 & 934 & 345 \\
\hline 1986 & 1145 & 431 \\
\hline 1987 & 2277 & 787 \\
\hline 1988 & 2674 & 768 \\
\hline 1989 & 2809 & 881 \\
\hline 1990 & 1872 & 591 \\
\hline 1991 & 2498 & 729 \\
\hline 1992 & 3687 & 1090 \\
\hline 1993 & 3705 & 1195 \\
\hline 1994 & 2959 & 956 \\
\hline 1995 & 3467 & 1040 \\
\hline 1996 & 3156 & 1024 \\
\hline 1997 & 4000 & 1483 \\
\hline 1998 & 4916 & 1699 \\
\hline 1999 & 7215 & 2998 \\
\hline 2000 & 7630 & 3457 \\
\hline 2001 & 9608 & 4698 \\
\hline 2002 & 7334 & 2982 \\
\hline 2003 & 7089 & 2481 \\
\hline 2004 & 5337 & 1619 \\
\hline 2005 & 5819 & 1612 \\
\hline 2006 & 6178 & 1484 \\
\hline 2007 & 5866 & 1432 \\
\hline 2008 & 7246 & 1665 \\
\hline 2009 & 11728 & 2634 \\
\hline 2010 & 11078 & 2340 \\
\hline Total & 137938 & 44799 \\
\hline
\end{tabular}

(Source: Citizenship and Immigration Canada - 2011 Landed Immigrant Data System, 1980-2010) 


\subsection{2: By Immigrant Class}

Until the late 1980s, most Koreans immigrated to Canada under the family class, but since 1987, a significant number of Koreans entered Canada under the entrepreneur class and independent class. It was early 1990s that economic class immigrants started to outnumber family class immigrants and around the same time, some Koreans started to enter the Toronto CMA as investor and entrepreneur immigrants. It is very clear that Korean immigration has shifted from family class to economic class in the 1990s. Canada's immigration policy emphasizing the economic aspects more than humanitarian aspects by focusing on skilled workers selected with the Point System, and the entrepreneur and investor programs in the 1990s provided more opportunities for Koreans to immigrate to Canada. There was a sudden increase on the number of Koreans under the independent class in 1999. The number almost doubled from 1,079 in 1998 to 1,938 in 1999 and hit the climax in 2001 at 3367. This figure indicates that a large number of educated skilled professionals chose Canada, particularly the Toronto CMA and the Vancouver CMA, as their new homes after the severe financial crisis took place in Korea in 1997. The other noticeable trend was that the number of entrepreneurs was at its peak in 2000 with 535 and started to decline after the year 2000 whereas the number of investor immigrants has been increased steadily throughout the 2000s. It seems that Koreans preferred the investor immigrant program over the entrepreneurs immigrant program as the latter program has a condition to start a proposed business in Canada within 2 years after becoming a permanent resident. This condition on the entrepreneur immigrant program put immense pressure and financial risk on new immigrants who do not have solid understanding of business practices in Canada. 
Table 4.2: Korean Immigrants in Canada by Immigration Category

\begin{tabular}{|l|l|l|l|l|}
\hline & 1998 & 2002 & 2006 & 2010 \\
\hline Skilled Worker and dependants & 1360 & 2330 & 1270 & 1085 \\
\hline Family Class & 245 & 370 & 500 & 530 \\
\hline Entrepreneur and dependants & 600 & 555 & 225 & 55 \\
\hline Investor and dependants & 315 & 315 & 425 & 450 \\
\hline Self-employed and dependants & 70 & 70 & 35 & 0 \\
\hline CEC and dependants & 0 & 0 & 0 & 90 \\
\hline PNP and Dependants & 0 & 125 & 930 & 1020 \\
\hline
\end{tabular}

(Source: Statistics Canada 2015. Tax Data in Landed Immigrant Data System)

Table 4.2 shows the number of Korean immigrants who filed their income tax for 2012 based on their landing year by immigration category from 1998 to 2010 . While the skilled worker program, formerly called independent program, had remained the most popular program among Korean immigrants, the number of Korean immigrants under the Provincial Nominee Programs have grown rapidly since 2002. In 2010, the number of skilled worker immigrants and their dependants was almost the same as Koreans under the Provincial Nominee Programs at 1,085 and 1,020 respectively. Both the Family Class and Investor immigrants had grown steadily from 1998 to 2010, but the number of Korean immigrants under the Entrepreneur Program had plunged from 600 in 1998 to 55 in 2010 . As the data were extracted from the 2012 CRA income data, they represent the number of Korean immigrants who filed the income tax for 2012 only. However, it can be a useful source to examine a more recent trend of Korean immigrants under different immigration programs. The majority of Koreans in recent years immigrated to Canada under the economy class such as the skilled worker, provincial nominee programs, entrepreneur and investor programs while a fair number of Koreans entered Canada under the family class. A relatively large number of entrepreneurs and investors in the Korean ethnic group may partially explain the high self-employment rate among Koreans, however, the main cause of high self- 
employment rate among Koreans can be more explicitly explained with socio-economic barriers that they experience in the mainstream labour market as suggested in the paper.
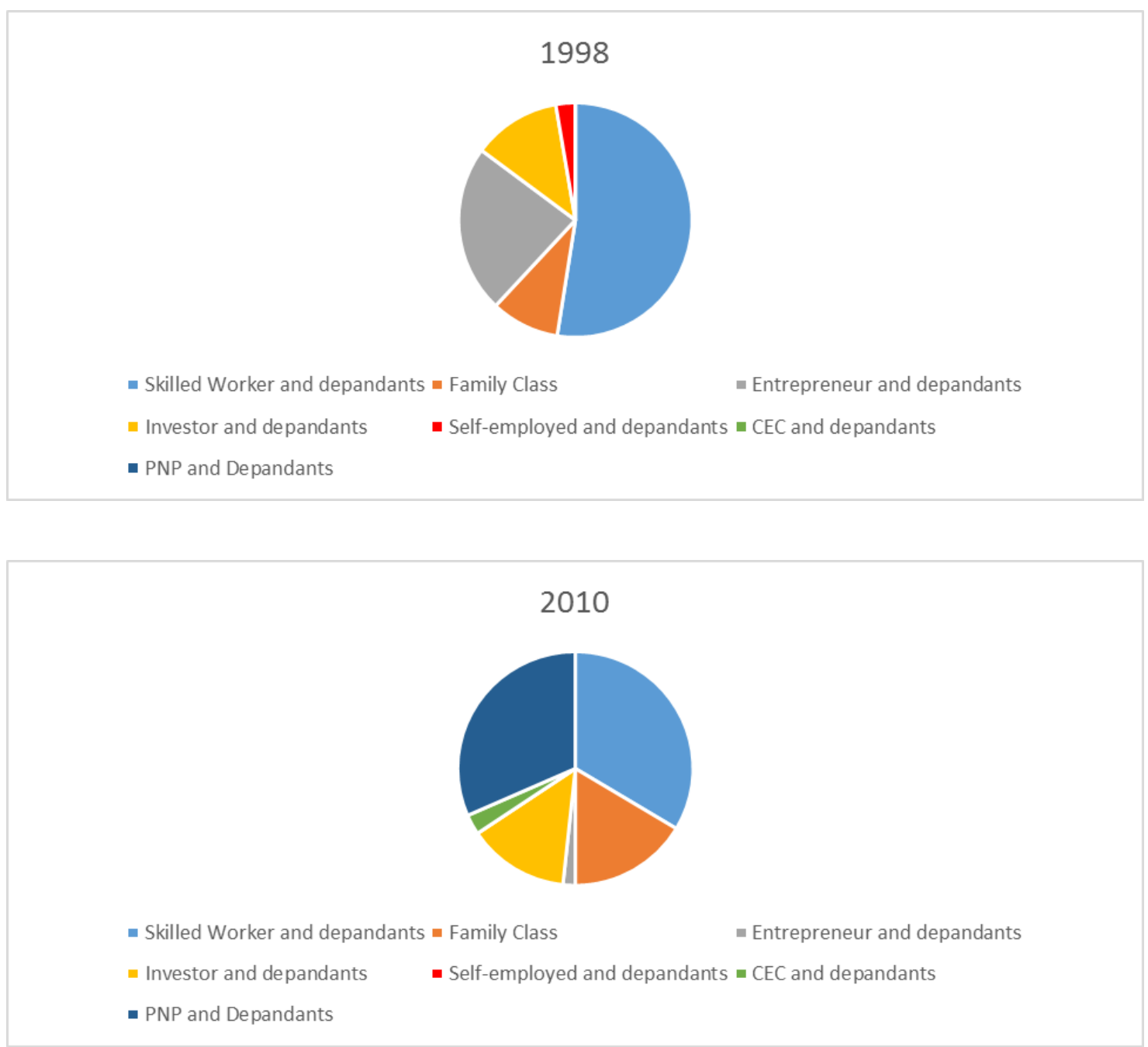

Figure 4.1: Korean Immigrants in Canada by Immigration Category, 1998 and 2010 (Source: Statistics Canada 2015. Tax Data in Landed Immigrant Data System)

Figure 4.1 shows the changing patterns of the different immigration programs that Koreans chose from 1998 to 2010. While the Skilled Worker Program was dominant in 1998 along with a strong presence of the Entrepreneur Program, in 2010 the Skilled Worker Program 
and new Provincial Nominee Programs were virtually tied, whereas the Family Class and Investor Program remained fairly strong, and the Entrepreneur Program nearly disappeared. Another noticeable change in 2010 was a strong start of the new Canadian Experience Class Program among Koreans.

\subsection{3: By Age}

Table 4.3 indicates that main Korean immigrants are in their 20's, 30's and 40's and their active participation in the Canadian labour market is expected as they are in their prime years to build their careers. The most Korean immigrants are either young adults with no children or families with young children or teenagers. The main motives of many Korean immigrants to choose Canada as their destination are to provide a better and less competitive education environment for their children or to pursue greater economic opportunities, and the data in Table 3 support the suggestion. 
Table 4.3: Korean immigrants in the Toronto CMA by Age Groups between 1980 and 2010

\begin{tabular}{|l|l|l|l|l|}
\hline \multicolumn{2}{|c|}{} & Numbers & Percent & $\begin{array}{l}\text { Cumulative } \\
\text { Percent }\end{array}$ \\
\hline & $0-4$ years old & 2364 & 5.3 & 5.3 \\
\hline $5-9$ years old & 4047 & 9.0 & 14.3 \\
\hline $10-14$ years old & 5188 & 11.6 & 25.9 \\
\hline $15-19$ years old & 4047 & 9.0 & 34.9 \\
\hline $20-24$ years old & 2009 & 4.5 & 39.4 \\
\hline $25-29$ years old & 3536 & 7.9 & 47.3 \\
\hline $30-34$ years old & 5127 & 11.4 & 58.7 \\
\hline $35-39$ years old & 5638 & 12.6 & 71.3 \\
\hline $40-44$ years old & 5681 & 12.7 & 84.0 \\
\hline $45-49$ years old & 3275 & 7.3 & 91.3 \\
\hline $50-54$ years old & 1200 & 2.7 & 94.0 \\
\hline $55-59$ years old & 728 & 1.6 & 95.6 \\
\hline $60-64$ years old & 706 & 1.6 & 97.2 \\
\hline $65-69$ years old & 596 & 1.3 & 98.5 \\
\hline $70-74$ years old & 361 & .8 & 99.3 \\
\hline $75-79$ years old & 194 & .4 & 99.8 \\
\hline $80-84$ years old & 69 & .2 & 99.9 \\
\hline $85-89$ years old & 28 & .1 & 100.0 \\
\hline $90-94$ years old & 4 & .0 & 100.0 \\
\hline $100-104$ years old & 1 & .0 & 100.0 \\
\hline Total & 44799 & 100.0 & \\
\hline
\end{tabular}

(Source: Citizenship and Immigration Canada - 2011 Landed Immigrant Data System, 1980-2010)

\subsection{4: By Education}

As shown in Table 4.4, from 1980 to 2010 , there was a total of 25,836 Korean immigrants between 20 and 55 years old who entered the Toronto CMA as new immigrants. Among the 25,836 Koreans, 14,893 (or 58\%) attained a bachelor's degree or higher. Korean immigrants possess one of the highest education levels among all immigrants and their average education level is also much higher than that of Canadian born individuals. With Canada's Point 
System focusing on education, experience and skills in the 1990s, a large number of highly educated Korean professionals entered Canada and settled in the Toronto CMA.

Table 4.4: Educational Qualifications

\begin{tabular}{|l|l|l|l|}
\hline & Frequency & Percent & $\begin{array}{l}\text { Cumulative } \\
\text { Percent }\end{array}$ \\
\hline None & 216 & 0.8 & 0.8 \\
\hline Secondary or Less & 5673 & 22.0 & 22.8 \\
\hline $\begin{array}{l}\text { Formal Trade Cert. or } \\
\text { Apprenticeship }\end{array}$ & 759 & 2.9 & 25.7 \\
\hline $\begin{array}{l}\text { Non-University ortificate } \\
\text { Diploma }\end{array}$ & 2877 & 11.1 & 36.8 \\
\hline $\begin{array}{l}\text { Some University- No } \\
\text { Degree }\end{array}$ & 1416 & 5.5 & 42.3 \\
\hline Bachelor's Degree & 10981 & 42.5 & 84.8 \\
\hline $\begin{array}{l}\text { Some Post Grad. } \\
\text { Education - No } \\
\text { Degree }\end{array}$ & 360 & 1.4 & 86.2 \\
\hline $\begin{array}{l}\text { Master's Degree } \\
\text { Doctorate }\end{array}$ & 608 & 11.4 & 100 \\
\hline Total & 25836 & 100 & 100 \\
\hline
\end{tabular}

(Source: Citizenship and Immigration Canada - 2011 Landed Immigrant Data System, 1980-2010)

\subsection{5: By Official Language Ability}

Based on the LIDS, $45.3 \%$ of Korean immigrants who settled in the Toronto CMA between 1980 and 2010 had English language ability while $54.2 \%$ of them reported that they had no official language ability. Less than $1 \%$ claimed that they were bilingual and only $0.1 \%$ spoke French. Further examination of official language ability is made for the age group between 20 and 55 . Table 4.5 shows that more than $40 \%$ of Koreans between the ages 20 and 55 in the 
Toronto CMA had no official language ability. Despite the high education level of Korean immigrants, their official language ability was very limited and this factor may have had a significant impact on their settlement patterns and economic performance in the Toronto CMA. It would be reasonable to argue that lack of the official language ability among Koreans is the main cause of their low economic participation in the mainstream labour market and their low economic performance.

\section{Table 4.5: Korean Adults (the Age between 20 and 55)' Canadian Language Ability}

\begin{tabular}{|l|l|l|}
\hline & Frequency & Percent \\
\hline English & 15,186 & $58.8 \%$ \\
\hline French & 25 & $0.1 \%$ \\
\hline Bilingual & 127 & $0.5 \%$ \\
\hline None & 10,498 & $40.6 \%$ \\
\hline Total & 25,836 & $100 \%$ \\
\hline
\end{tabular}

(Source: Citizenship and Immigration Canada - 2011 Landed Immigrant Data System, 1980-2010)

\section{2: Economic Performance}

Most Korean immigrants came to Canada with social, financial and/or human capital, and they were expected to have a relatively smooth transition to the Canadian society and financially perform better than other ethnic groups that bring large numbers of refugees to Canada with little social, financial or human capital. However, the employment income tax data for Koreans do not reflect this expectation. The Korean ethnic group's reported personal income was much lower than the average of Canadian born individuals and a much larger proportion of the Korean population falls below the low income cut-off (Park, 2012; Lindsay, 2007). 


\subsection{1: Employment Income}

According to Statistics Canada, the average employment income of the Korean ethnic group in 2006 was one of the lowest among racialized ethnic groups. Table 4.6 shows that employment income in 2006 was \$30,474 for Korean men and \$21,112 for Korean women. These incomes are the second lowest among racialized groups for both sexes.

Table 4.6: Average Employment Income by Racialized Group

\begin{tabular}{|l|l|l|}
\hline & Men & Women \\
\hline Arab & $\$ 34,171$ & $\$ 21,874$ \\
\hline Black & $\$ 31,233$ & $\$ 25,336$ \\
\hline Chinese & $\$ 38,342$ & $\$ 27,745$ \\
\hline Filipino & $\$ 33,141$ & $\$ 26,960$ \\
\hline Latin American & $\$ 31,187$ & $\$ 20,802$ \\
\hline Japanese & $\$ 60,004$ & $\$ 32,647$ \\
\hline Korean & $\$ \mathbf{3 0 , 4 7 4}$ & $\mathbf{\$ 2 1 , 1 2 2}$ \\
\hline South Asian & $\$ 36,904$ & $\$ 24,081$ \\
\hline South East Asian & $\$ 34,270$ & $\$ 23,325$ \\
\hline West Asian & $\$ 30,173$ & $\$ 21,234$ \\
\hline Total Racialized & $\$ 35,329$ & $\$ 25,204$ \\
\hline
\end{tabular}

(Source: Statistics Canada - 2006 Census)

While this research focuses on the Korean immigrants in the Toronto CMA, the nationwide employment income and self-employment income data for year 2012 by each landing year between 1998 and 2012 are analyzed for more recent economic performances of the Korean immigrants in Canada. For this reason, as stated in the methodology chapter, some degree of generalization is applied to examine Korean immigrants in the Toronto CMA. The average employment income of all immigrants who landed in 1998 was $\$ 47,000$ whereas the Korean immigrants' average employment income for the same landing year was $\$ 35,000$. The average 
income of Korean immigrants was much lower than the average income of total immigrants and it was the second lowest among the sample immigrant groups shown in Table 4.7.

Table 4.7: Average Employment Income for 2012 by Each Landed Year

\begin{tabular}{|l|l|l|l|l|l|l|l|l|}
\hline Country & 1998 & 2000 & 2002 & 2004 & 2006 & 2008 & 2010 & 2012 \\
\hline $\begin{array}{l}\text { Total } \\
\text { Immigrants }\end{array}$ & $\$ 47,000$ & $\$ 48,000$ & $\$ 44,000$ & $\$ 41,000$ & $\$ 36,000$ & $\$ 33,000$ & $\$ 30,000$ & $\$ 23,000$ \\
\hline Korean & $\$ 35,000$ & $\$ 35,000$ & $\$ 35,000$ & $\$ 30,000$ & $\$ 28,000$ & $\$ 26,000$ & $\$ 24,000$ & $\$ 24,000$ \\
\hline Chinese & $\$ 49,000$ & $\$ 53,000$ & $\$ 43,000$ & $\$ 36,000$ & $\$ 29,000$ & $\$ 26,000$ & $\$ 22,000$ & $\$ 16,600$ \\
\hline Filipino & $\$ 44,000$ & $\$ 46,000$ & $\$ 48,000$ & $\$ 40,000$ & $\$ 36,000$ & $\$ 32,000$ & $\$ 29,000$ & $\$ 20,000$ \\
\hline Vietnamese & $\$ 28,000$ & $\$ 28,000$ & $\$ 25,000$ & $\$ 24,000$ & $\$ 23,000$ & $\$ 21,000$ & $\$ 19,100$ & $\$ 13,400$ \\
\hline Indian & $\$ 40,000$ & $\$ 43,000$ & $\$ 40,000$ & $\$ 40,000$ & $\$ 32,000$ & $\$ 30,000$ & $\$ 28,000$ & $\$ 18,500$ \\
\hline Nigerian & $\$ 52,000$ & $\$ 59,000$ & $\$ 57,000$ & $\$ 47,000$ & $\$ 45,000$ & $\$ 37,000$ & $\$ 32,000$ & $\$ 22,000$ \\
\hline Iranian & $\$ 49,000$ & $\$ 45,000$ & $\$ 46,000$ & $\$ 40,000$ & $\$ 36,000$ & $\$ 28,000$ & $\$ 26,000$ & $\$ 14,700$ \\
\hline Mexican & $\$ 49,000$ & $\$ 44,000$ & $\$ 46,000$ & $\$ 43,000$ & $\$ 36,000$ & $\$ 34,000$ & $\$ 33,000$ & $\$ 29,000$ \\
\hline Russian & $\$ 57,000$ & $\$ 55,000$ & $\$ 49,000$ & $\$ 47,000$ & $\$ 41,000$ & $\$ 36,000$ & $\$ 34,000$ & $\$ 27,000$ \\
\hline American & $\$ 67,000$ & $\$ 65,000$ & $\$ 59,000$ & $\$ 62,000$ & $\$ 54,000$ & $\$ 58,000$ & $\$ 52,000$ & $\$ 52,000$ \\
\hline English & $\$ 77,000$ & $\$ 72,000$ & $\$ 69,000$ & $\$ 70,000$ & $\$ 65,000$ & $\$ 60,000$ & $\$ 54,000$ & $\$ 57,000$ \\
\hline
\end{tabular}

(Source: Statistics Canada 2015. Tax Data in Landed Immigrant Data System)

Both total immigrants and Koreans who landed in 2000 had the highest average employment income at $\$ 48,000$ and $\$ 35,000$ respectively. The average employment income for total immigrants who landed in 2010 was $\$ 30,000$ and $\$ 24,000$ for the Korean immigrants. Therefore, the newer the both immigrant groups were, the lower the employment income they reported, but the income gap between the two immigrant groups widened over time. The income gap between the two groups became bigger from $\$ 13,000$ for the immigrants who landed in 2000 to $\$ 6,000$ for immigrants who landed in 2010. As shown in Figure 4.2, there was less of an income gap among newer immigrants between total immigrants and Korean immigrants, meaning that the longer they lived in Canada, the bigger income gap they had between total immigrants and Korean immigrants. While both total immigrants and Korean immigrants 
improve their economic performance in the Canadian labour market over time, the income gap between the two groups broadened, which can be concluded that Koreans experience much less economic upward mobility than most immigrant groups in the Canadian labour market.

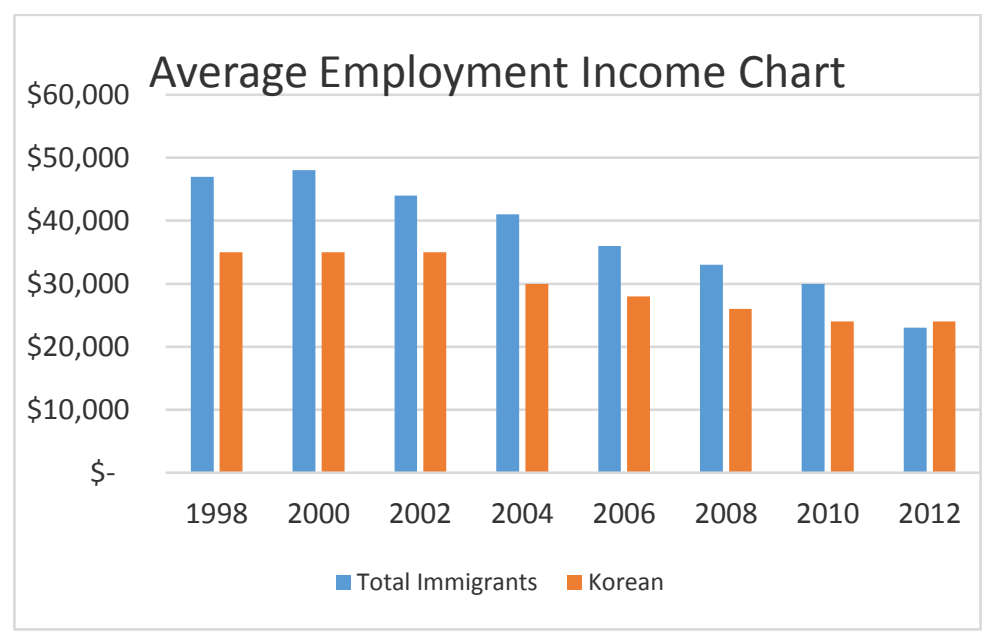

Figure 4.2: Average Employment Income Chart

(Source: Statistics Canada 2015. Tax Data in Landed Immigrant Data System)

As shown in Figure 4.3, the employment income of racialized immigrants was much lower than that of British or American immigrants. Figure 4.3 also indicates that the increase of employment income over the years for Korean, Vietnamese, Mexican, American and British immigrants was mild, but the Chinese, Filipino, Nigerian, Iranian and Russian immigrants have experienced a more stiff upward economic mobility over the years, as their employment income increased on a much larger scale. Based on the data, it would be fair to suggest that racialized new immigrants in general face much harder socio-economic barriers than new European or American immigrants and immigrants who do not speak fluent official languages experience much milder financial gains over the years in the Canadian labour market. 


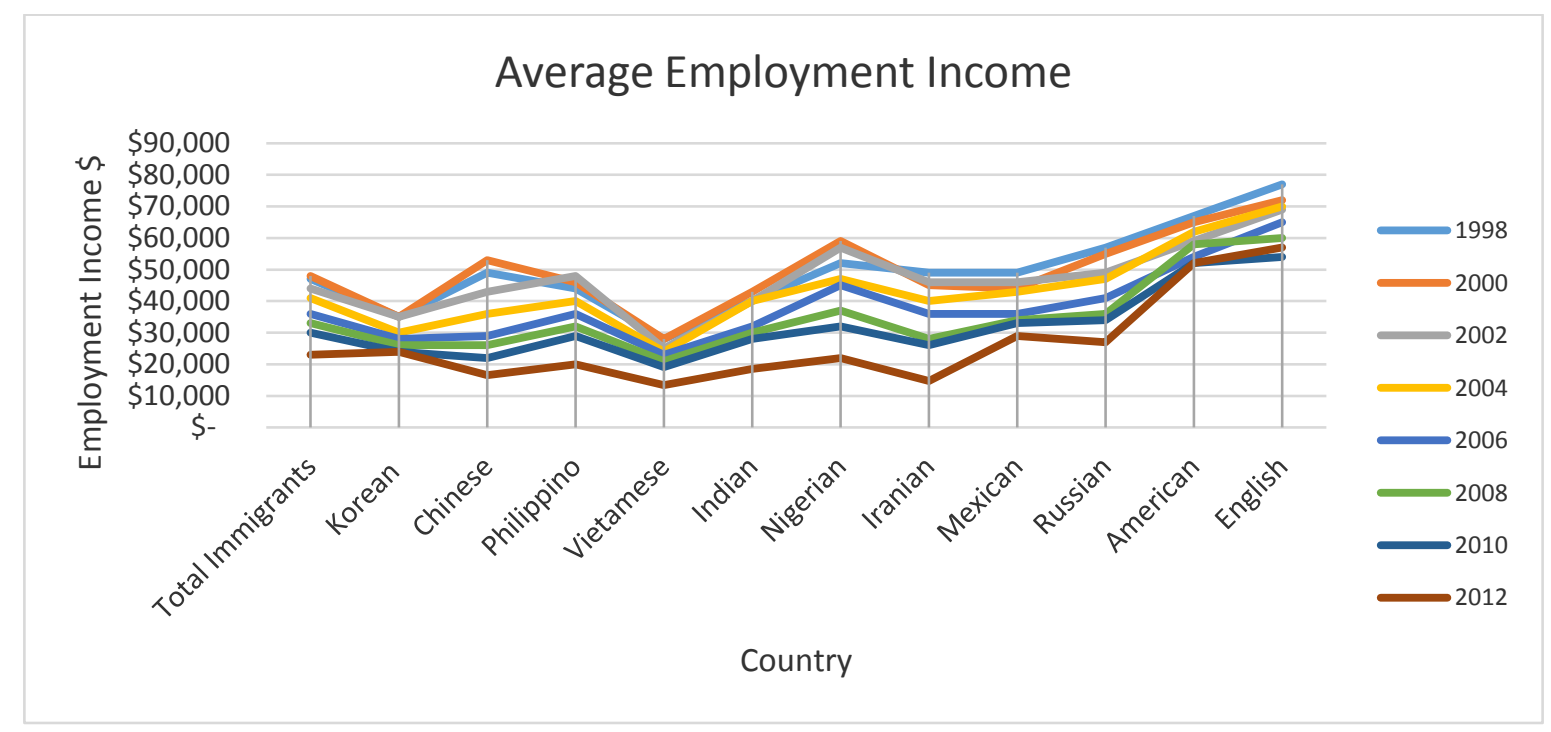

Figure 4.3: Average Employment Income by Country

(Source: Statistics Canada 2015. Tax Data in Landed Immigrant Data System)

Table 4.8 shows the employment income for year 2012 of the Korean immigrants by their landing year and immigration category. The Korean immigrants who immigrated to Canada under the Skilled Worker Program had the highest income for all landing years except 2010 and 2012 while the Investor immigrants had the second highest income overall. The noticeable fact was that the Korean immigrants under the Entrepreneurs and Self-employed Programs reported the lowest employment income among all Korean immigrants. The Korean immigrants with the Canadian Experience Class Program which was introduced in 2009 showed the highest employment income for 2010 and 2012 as they already had a job in Canada before they became permanent residents in Canada. 
Table 4.8: Korean Immigrants' Employment Income by Immigration Category and Landing Year (for 2012 Tax Year)

\begin{tabular}{|c|c|c|c|c|c|c|c|c|c|c|}
\hline Landing Year & \multicolumn{2}{|c|}{1998} & \multicolumn{2}{|c|}{2002} & \multicolumn{2}{|c|}{2006} & \multicolumn{2}{|c|}{2010} & \multicolumn{2}{|c|}{2012} \\
\hline Skilled Worker (SW) & $\$$ & 46,000 & $\$$ & 48,000 & $\$$ & 45,000 & $\$$ & 37,000 & $\$$ & 33,000 \\
\hline SW Family Members & $\$$ & 30,000 & $\$$ & 27,000 & $\$$ & 22,000 & $\$$ & 13,200 & $\$$ & 13,500 \\
\hline $\begin{array}{l}\text { Family Class: Spouse \& } \\
\text { Partner }\end{array}$ & $\$$ & 33,000 & $\$$ & 32,000 & $\$$ & 29,000 & $\$$ & 22,000 & $\$$ & 14,400 \\
\hline Entrepreneur & $\$$ & 26,000 & $\$$ & 30,000 & $\$$ & 23,000 & $\$$ & 16,000 & $\$$ & - \\
\hline $\begin{array}{l}\text { Entrepreneur Family } \\
\text { Members }\end{array}$ & $\$$ & 27,000 & $\$$ & 26,000 & $\$$ & 15,500 & $\$$ & 14,600 & $\$$ & - \\
\hline Investor & $\$$ & 37,000 & $\$$ & 27,000 & $\$$ & 25,000 & $\$$ & 30,000 & $\$$ & 22,000 \\
\hline Investor Family Members & $\$$ & 34,000 & $\$$ & 26,000 & $\$$ & 16,700 & $\$$ & 8,500 & $\$$ & 8,800 \\
\hline Self-employed & $\$$ & 23,000 & $\$$ & 25,000 & $\$$ & 18,000 & $\$$ & - & $\$$ & - \\
\hline $\begin{array}{l}\text { Self-employed Family } \\
\text { Members }\end{array}$ & $\$$ & 33,000 & $\$$ & 26,000 & $\$$ & 15,600 & $\$$ & - & $\$$ & - \\
\hline \multicolumn{11}{|l|}{ PNP } \\
\hline \multicolumn{11}{|l|}{ PNP Family Members } \\
\hline $\begin{array}{l}\text { Canadian Experience } \\
\text { Class (CEC) }\end{array}$ & & & & & & & $\$$ & 38,000 & $\$$ & 35,000 \\
\hline CEC Family Members & & & & & & & $\$$ & 34,000 & $\$$ & 14,500 \\
\hline
\end{tabular}

(Source: Statistics Canada 2015. Tax Data in Landed Immigrant Data System)

\subsection{2: Self-employment Income}

It is important to analyze the self-employment income data separately to understand the Korean immigrants' economic performance, because they have the highest self-employment rate among all ethnic groups in Canada: above 30 percent. Self-employment income is typically much lower than employment income and it could be one of the main factors that caused the overall low income status among Korean immigrants. As shown in Table 4.9, the average selfemployment income of 2012 for total immigrants who landed in 1998 was \$13,400; however, that of Korean immigrants who landed in the same year was $\$ 15,100$ which is the highest among racialized immigrants. In contrast to the total immigrant group, the average self-employment income of Korean immigrants who landed in 2012 was less than half of the average income of Koreans who landed in 1998 at \$7,300 whereas the average self-employment income for total 
immigrants who landed in 2012 was $\$ 11,300$. While the average self-employment income of newer Koreans was lower than that of total immigrants, unlike what the employment income data show, the longer the self-employed Koreans resided in Canada, the better they performed financially than the total immigrants. The overall economic performance of self-employed Koreans was better than that of total immigrants.

Table 4.9: Average Self-employment Income Chart in 2012 by Landing Year

\begin{tabular}{|c|c|c|c|c|c|c|c|c|c|}
\hline & & 1998 & 2000 & 2002 & 2004 & 2006 & 2008 & 2010 & 2012 \\
\hline Immigrants & & 13,400 & $\$ 13,300$ & $\$ 12,600$ & $\$ 13,000$ & $\$ 11,900$ & $\$ 11,600$ & $\$ 11,100$ & $\$ 11,300$ \\
\hline Korean & & 15,100 & $\$ 13,800$ & $\$ 13,700$ & $\$ 11,600$ & $\$ 12,200$ & $\$ 10,500$ & $\$ \quad 8,600$ & $\$ \quad 7,300$ \\
\hline Chinese & & 11,400 & $\$ 10,900$ & $\$ 10,600$ & $\$ 10,000$ & $\$ 9,300$ & $\$ 9,800$ & 8,400 & 6,200 \\
\hline Filipino & & 7,500 & $\$ 8,200$ & $\$ 8,100$ & $\$ 7,600$ & $\$ \quad 6,800$ & $\$ \quad 6,500$ & $\$ \quad 6,400$ & $\$ \quad 5,700$ \\
\hline Vietnamese & $\$$ & 11,600 & $\$ 10,800$ & $\$ 12,600$ & $\$ 9,200$ & $\$ 10,100$ & $\$ 10,700$ & $\$ \quad 8,300$ & 6,200 \\
\hline Indian & $\$$ & 14,700 & $\$ 14,800$ & $\$ 13,200$ & $\$ 12,300$ & $\$ 11,300$ & $\$ 10,500$ & $\$ \quad 9,300$ & $\$ \quad 7,800$ \\
\hline Nigerian & $\$$ & 12,700 & $\$ 11,800$ & $\$ 10,100$ & $\$ 7,900$ & $\$ 9,400$ & $\$ 7,900$ & $\$ \quad 9,700$ & $\$ 14,000$ \\
\hline Iranian & $\$$ & 13,400 & $\$ 16,100$ & $\$ 13,500$ & $\$ 14,300$ & $\$ 11,800$ & $\$ 10,100$ & $\$ \quad 9,400$ & $\$ \quad 7,300$ \\
\hline Mexican & $\$$ & 13,000 & $\$ 12,300$ & $\$ 11,800$ & $\$ \quad 8,700$ & $\$ 10,100$ & $\$ 9,100$ & $\$ 10,200$ & $\$ 10,700$ \\
\hline Russian & $\$$ & 12,300 & $\$ 10,500$ & $\$ 10,100$ & $\$ 10,100$ & $\$ 11,000$ & $\$ \quad 9,600$ & $\$ \quad 9,700$ & $\$ \quad 7,800$ \\
\hline American & $\$$ & 19,900 & $\$ 21,000$ & $\$ 18,100$ & $\$ 19,100$ & $\$ 16,500$ & $\$ 15,600$ & $\$ 19,800$ & $\$ 20,000$ \\
\hline English & $\$$ & 22,000 & $\$ 18,800$ & $\$ 14,600$ & $\$ 23,000$ & $\$ 15,700$ & $\$ 16,000$ & $\$ 16,100$ & $\$ 29,000$ \\
\hline
\end{tabular}

(Source: Statistics Canada 2015. Tax Data in Landed Immigrant Data System)

Figure 4.4 shows how the average self-employment incomes over the years between total immigrants and Korean immigrants have reversed. There was not much of an income difference between the total immigrants who landed in 2012 and those who landed in 1998 whereas significant income gains were witnessed among Koreans as they lived in Canada longer. 


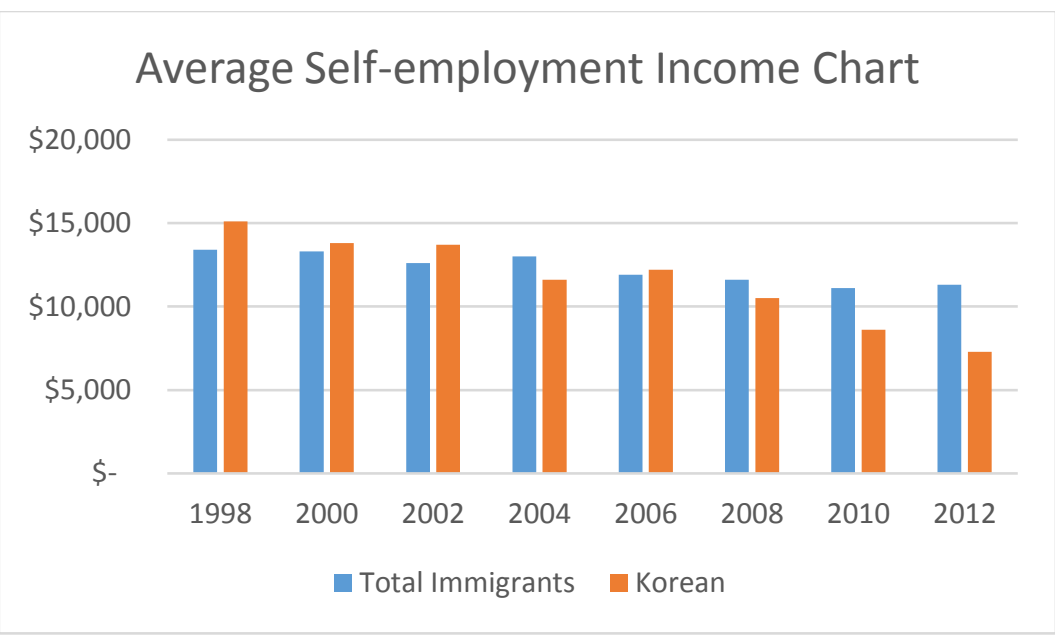

Figure 4.4: Average Self-employment Income Chart

(Source: Statistics Canada 2015. Tax Data in Landed Immigrant Data System)

Contrary to the average employment income, Figure 4.5 shows that self-employed Korean immigrants have experienced bigger financial gains over the years along with some other racialized immigrant groups such as Vietnamese and Iranian. It seems that Koreans have achieved higher economic gains as self-employed rather than as employees even though the average self-employment income was much lower than that of the employment income and it may explain the high self-employment rate among Koreans. Similar to their employment income, the average self-employment income of immigrants from the U.S. and England was much higher than the average self-employment income of other immigrants. Both the employment and selfemployment income data shows the immigrants from U.S. and England outperformed all the other immigrant groups as they faced less barriers partially due to their official language ability.

As shown in Figure 4.5, the spectrum of the average self-employment income for Koreans who landed between the years 1998 and 2012 was much wider than that of the total 
immigrants which indicates that Koreans experienced much higher self-employment income gains over the years than most of the other immigrant groups.

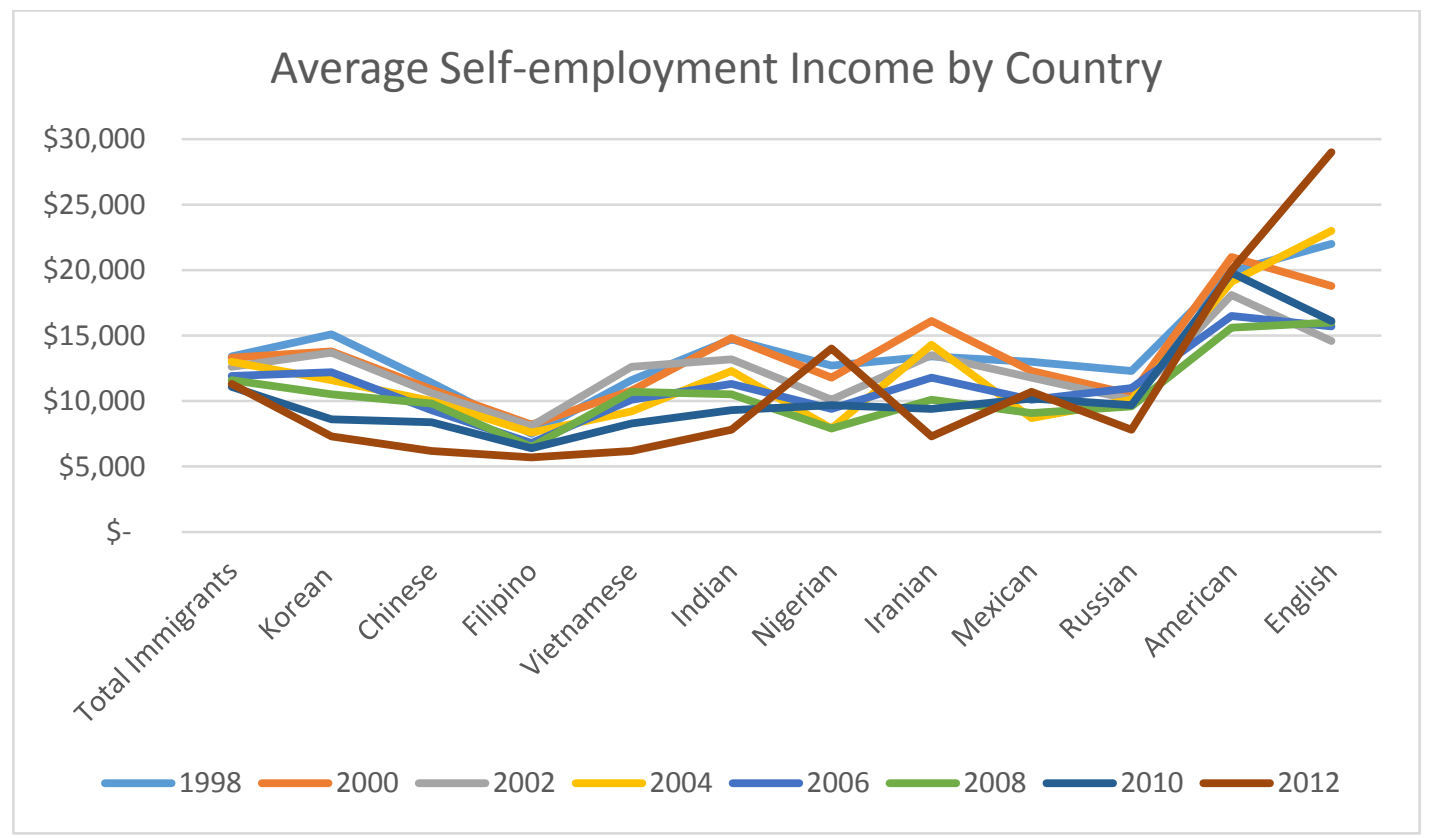

Figure 4.5: Average Self-employment Income in 2012, by Country and Landing Year (Source: Statistics Canada 2015. Tax Data in Landed Immigrant Data System)

Table 4.10 provides self-employment income for the year 2012 of the Korean immigrants by their landing year and immigration category. The investor immigrants reported the highest self-employment income overall among the Korean immigrants, while the Skilled Worker immigrants earned the second highest self-employment income. The entrepreneur and selfemployed immigrant groups reported the lowest self-employment income as well. 


\section{Table 4.10: Self-employment Income in 2012, by Immigration Category and Landing Year}

\begin{tabular}{|c|c|c|c|c|c|c|c|c|}
\hline & \multicolumn{2}{|c|}{1998} & \multirow{2}{*}{$\begin{array}{l}2002 \\
\$ 15,300\end{array}$} & \multirow{2}{*}{$\begin{array}{l}2006 \\
\$ 13,900\end{array}$} & \multicolumn{2}{|c|}{2010} & \multicolumn{2}{|c|}{2012} \\
\hline Skilled Worker (SW) & & 17,700 & & & $\$$ & 5,300 & $\$$ & 4,900 \\
\hline SW Family Members & & 15,600 & $\$ 12,200$ & $\$ 11,700$ & $\$$ & 9,500 & $\$$ & 11,400 \\
\hline Family Class: Spouse \& Partner & $\$$ & 10,900 & $\$ 11,300$ & $\$ 10,400$ & $\$$ & 8,400 & $\$$ & 9,500 \\
\hline Entrepreneur & $\$$ & 12,100 & $\$ 12,400$ & $\$ 11,500$ & $\$$ & 13,100 & $\$$ & - \\
\hline Entrepreneur Family Members & $\$$ & 11,600 & $\$ 9,900$ & $\$ 7,500$ & $\$$ & - & $\$$ & - \\
\hline Investor & $\$$ & 13,600 & $\$ 19,600$ & $\$ 22,000$ & $\$$ & 10,200 & $\$$ & - \\
\hline Investor Family Members & $\$$ & 23,000 & $\$ 10,900$ & $\$ \quad 6,700$ & $\$$ & 11,400 & $\$$ & - \\
\hline Self-employed & $\$$ & 8,200 & $\$ 10,700$ & $\$$ & $\$$ & - & $\$$ & - \\
\hline Self-employed Family Members & $\$$ & 4,100 & $\$ 11,800$ & $\$$ & $\$$ & - & $\$$ & - \\
\hline PNP & $\$$ & - & $\$ 20,000$ & $\$ 15,800$ & $\$$ & 10,300 & $\$$ & 5,200 \\
\hline
\end{tabular}

(Source: Statistics Canada 2015. Tax Data in Landed Immigrant Data System)

It is reasonable to conclude that despite the high level of human capital, many Korean immigrants encounter a high level of difficulty integrating into the Canadian labour market, mainly due to systemic and language barriers. Korean immigrants' official language barriers forced many of them to stay in the Korean ethnic businesses resulting in a high self-employment rate. Couton (2014) stated that "Korean entrepreneurship in Canada appears to be more of a defensive strategy than a path to successful economic integration." It can be argued that the Koreans' low reported personal income is linked to high self-employment and entrepreneurship rate in the Korean community and heavy reliance of co-ethnic employment opportunity, because wages in the ethnic economy is much lower than that of the mainstream economy. As selfemployed individuals have a legitimate way to reduce their personal income by deducting business expenses and entrepreneurs could have separate business incomes, the Korean immigrants' actual earning power may be greater than reported and it may explain a high level of home ownership among Korean immigrants in Canada. 


\section{3: Settlement Patterns}

Most Koreans have settled in urban centres, particularly in Toronto and Vancouver. According to the 2006 Canadian census, the total number of Korean immigrants in Canada was 95,965. When Korean temporary residents such as international students and foreign workers are included, the total number was 146,550 . The Korean immigrant population is concentrated in Ontario (49 per cent) and British Columbia (35 per cent), with most living in Toronto and Vancouver (Bai, 2006). The Toronto CMA's Korean population in 2011 was 61,300, consisting of $1 \%$ of the total population of the Toronto CMA (Statistics Canada 2011).

In the past, immigrants settled down in the inner city of the major urban centers, but the immigration settlement pattern in the Toronto CMA has shifted from traditional inner- city settlement to the suburbs (Murdie and Teixeira, 2003). Korean immigrants in the Toronto CMA has been following this settlement trend in the recent decades, resulting in the formation of Korean clusters in North York along Yonge Street between Sheppard Avenue and Steeles Street.

With a fast growing economy, Korea has generated a large number of middle income class who are highly educated and professionals. Many of them immigrated to Canada in the 1990s and 2000s for better quality of living and, in many cases, for better education for their

children. As they were economically secure, they were able to settle down in the suburban areas, particularly in North York where many good schools are located for their children. This new settlement trend formed a new Korean cluster in North York, and the Yonge and Finch area has become a new business centre for the Korean community in the Toronto CMA.

While the Koreantown in downtown Toronto remains as an active ethnic business centre for the Korean community, very few Koreans live in the area nowadays. In contrast, many 
Koreans settled in North York and as a result, more Korean businesses have been established in the area. As Koreatown in downtown Toronto has been saturated with similar type of small ethnic businesses in the limited retail space, many new Korean immigrants opened ethnic businesses in North York. As the Korean population grows in the area, more diverse ethnic businesses were created to meet the consumer demands. As a result, many Koreans work and live in the same area, and many Korean ethnic businesses rely on ethnic resources for both labour and customers ( $\mathrm{Li}, 1998)$.

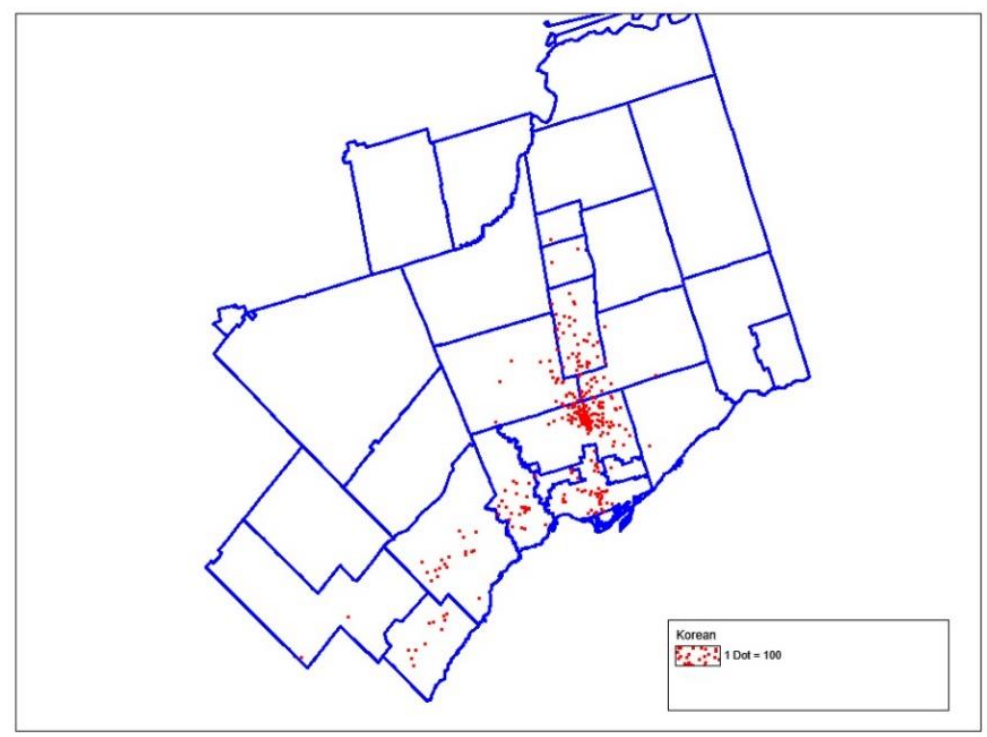

Figure 4.6: Settlement Pattern of Korean Immigrants in the Toronto CMA (Source: 2006 Census)

Figure 4.6 shows the heavy concentration of the Korean population in North York and Thornhill along Yonge Street whereas a modest Korean population resides in downtown Toronto, Etobicoke, Richmond Hill, Mississauga, Oakville and Burlington. 


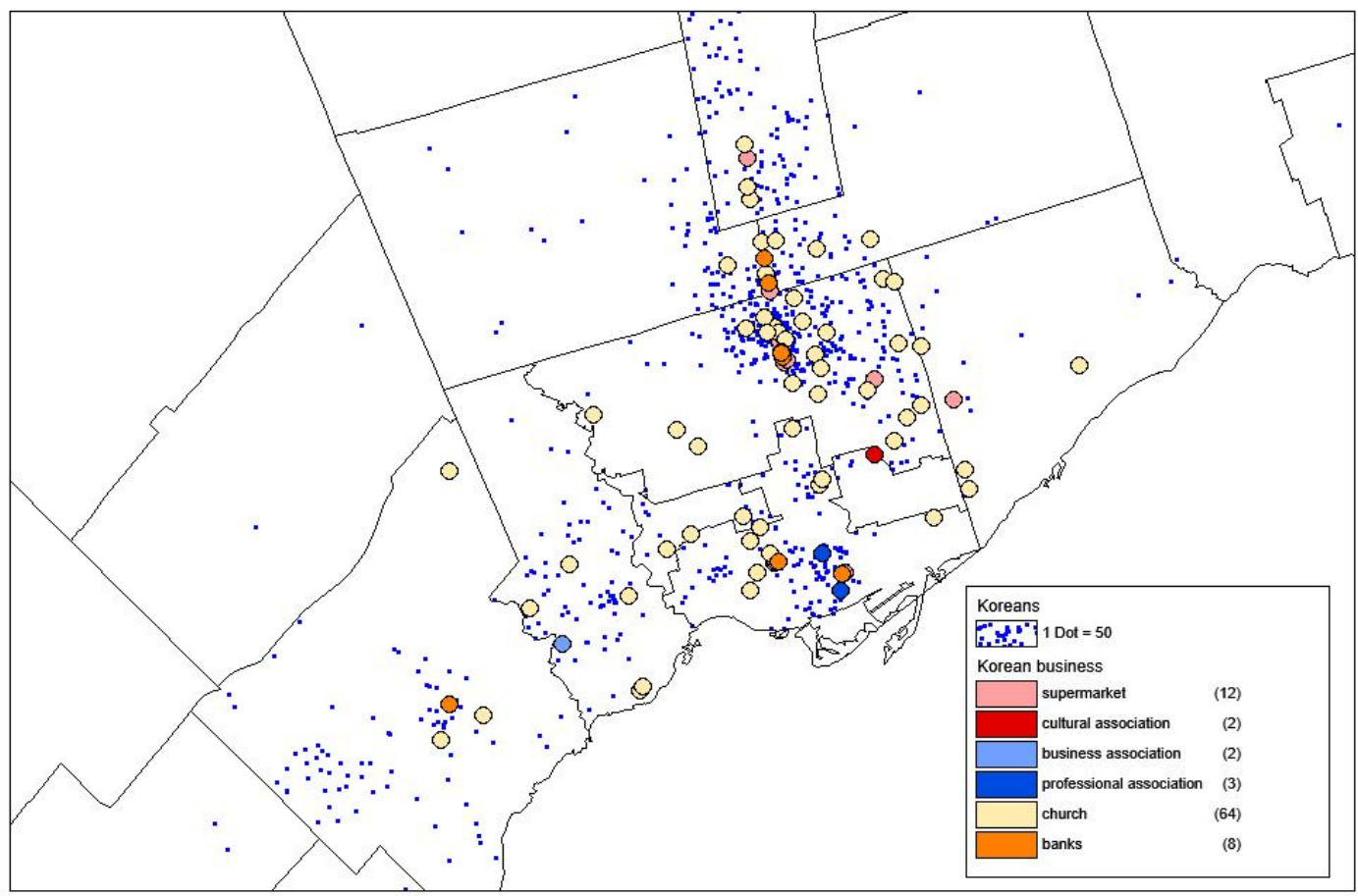

\section{Figure 4.7: Geographical Distribution of Korean Businesses, Cultural and Religious Institutions in the Toronto CMA}

(Source: 2006 Census and Korean Business Directory, the Korea Times Daily)

Figure 4.7 shows the Korean population and major business, cultural and religious institutions in the Toronto CMA. The blue dots indicate the Korean population and Yellow circles indicate the Korean Presbyterian Churches. Brown circles represent Korean banks and pink circles show where the Korean ethnic supermarkets are located in the Toronto CMA. Seven out of Twelve Korean supermarkets are located in North York and Four out of Eight Korean banks are cited in North York as well. While Korean churches are scattered throughout the Toronto CMA, the locations of the Churches are somewhat aligned with where Koreans reside in the Toronto CMA. Even though the data collected from the business directory of the Korea 
Times Daily are limited, it is quite evident that there are both high concentration of Korean population and the Korean businesses in North York. As Li (1998) described it, "Ethnoburbs can be recognised as suburban ethnic clusters of residential areas and business districts in large metropolitan areas". With these findings, it is fair to conclude that a Korean "Ethnoburb" has been formed in North York in the Toronto CMA.

Suburban ethnic communities or "Ethnoburbs" are often called transnational communities as they have close transnational ties with their home countries. Similar to other major transnational communities in the Toronto CMA (such as the South Asian community in Brampton and the Chinese community in Markham), the Korean transnational community in North York has strong socio-economic ties with Korea, which creates a distinct feature of the Korean community and its formation is more likely to be based on the combination of their business or employment opportunities and the preference of the Koreans to stay within their own community for easy transition and a sense of belonging. I would argue that the formation of Korean suburban community in North York is a result of both a defensive strategy to overcome the socio-economic barriers they face in the mainstream society and a preference to settle in their own community for convenience and sense of belonging under Canada's multiculturalism policy that promotes a cultural mosaic.

\section{4: Korean Ethnic Business}

Korean ethnic businesses in the Toronto CMA have grown and have diversified rapidly over the last two decades. With a high entrepreneurship rate in the Korean community, various service sectors including restaurants, insurance/finance/investment services, private educational 
institutions, travel agencies and real estate agents have expanded drastically. In particular, the proliferation of restaurants and private education businesses is quite noticeable and this phenomenon can be explained with Hibert's (2002) “training system” within the Korean ethnic economy. Many Koreans turned to Korean ethnic institutions such as restaurants and private educational institutes as they faced various systemic barriers in the Canadian labour market. After receiving the necessary training, many of them either became self-employed or started their own businesses and hired other Koreans. Through this process, the disadvantaged Korean labour market became more saturated, which led to low economic returns among Korean immigrants. Table 4.11 shows the sharp increase of the number of major Korean ethnic businesses from 1998 to 2016 in the Toronto CMA. In addition, there are currently a total of 8 Korean bank branches, 69 Korean-Canadian lawyers and 14 Korean-Canadian family doctors in the Toronto CMA (Korea Times Daily, 2016).

Diverse professional backgrounds of Korean immigrants may have contributed to diversification of professions in the Korean ethnic enclave economy in the Toronto CMA. On the other hand, many Korean immigrants also opened small retail stores such as convenience stores, drycleaners, restaurants and flower shops outside of the Korean ethnic business area in the Toronto CMA. They use their personal networks identified as ethnic businesses. 
Table 4.11: Major Korean Ethnic Businesses in the Toronto CMA

\begin{tabular}{|c|c|c|}
\hline Category & 1998 & 2016 \\
\hline Business & No. of Business & No. of Business \\
\hline Restaurant & 87 & 215 \\
\hline Real Estate Agent & 48 & 411 \\
\hline Private Educational Institute & 34 & 126 \\
\hline Insurance/Finance/Investment & 29 & 143 \\
\hline Travel Agency & 28 & 39 \\
\hline Accounting & 25 & 52 \\
\hline
\end{tabular}

(Source: Ontario Korean Business Directory, the Korea Times Daily)

A noticeable recent change in the Korean ethnic business in the Toronto CMA is the fast increase of large-scale Korean supermarkets. Some of these supermarkets are as large as the mainstream Canadian supermarkets and they provide excellent services with both imported Korean food products and Canadian food products. These Korean supermarkets promote active transnational activities among Koreans by importing and exporting trendy Korean products on a daily basis through their transnational networks to be highlighted in the case study. Currently, there are 12 major Korean supermarkets in the Toronto CMA and 8 of them are concentrated in North York and Richmond Hill where the majority of Koreans in the Toronto CMA reside. In particular, the Galleria Supermarket is often compared to T\&T supermarket in the Chinese community for its big scale and high quality of customer services in the Toronto CMA.

While most Korean retail businesses remain small and they are ethnic community serving businesses, these larger Korean supermarkets are not only targeting Koreans but also, other ethnic groups including Chinese by providing diverse products and services in Korean, English and Chinese languages. As Wang and Du (2012) pointed out, it is important for immigrant entrepreneurs to learn the broad knowledge of the Canadian business environment that entails a balance between economic development and community life, and be sensitive to the different 
needs of communities composed of ethnically diverse people, and expand their business to diverse groups of people and integrate into the Canadian society.

\section{5: Case Study - Korean Supermarket Chains}

Three major Korean supermarket chains in the Toronto CMA are examined in this case study. The purpose of this case study is to examine how these Korean ethnic businesses adopted increasing transnational activities among Korean immigrants in the Toronto CMA and utilized transnational and mixed economy strategies to expand their businesses not only within the Korean community but also to other ethnic communities in the Toronto CMA. They play important roles in the Korean community and represent major ethnic entrepreneurs, co-ethnic employers, and active transnational actors. In some cases, they also act as community centres. While there are many similarities among these businesses, some significant differences exist. This case study illustrates these supermarket chains' rather complex and multi-layered functions in the current Korean ethnic economy and community and how they affected settlement experiences of Korean immigrants in the Toronto CMA.

\subsection{1: Galleria Supermarket}

Galleria Supermarket opened its first store in Thornhill, Ontario in November 2003 and the second store in York Mills in November 2010 (Galleria 2016). Since its inception, Galleria has become the most loved Korean supermarket chain among Korean immigrants with its spacious and clean stores that are similar to the mainstream supermarkets such as Loblaws and Metro, serving a broad range of Korean and other Asian products. Galleria Supermarket has 
become a game changer in the Korean community within the Toronto CMA with its innovative and customer oriented management strategies. It implemented the first self-checkout cashier stations among North American Korean Supermarkets in February 2009 and has provided various cultural events including Korean cooking classes and sponsored various Korean community programs (Galleria 2016).

Galleria is also the first Korean supermarket in the Toronto CMA that hosts a food court and other specialized retail stores such as travel agency, Korean cosmetic shops, Korean gift and handcraft shop and jewellery shop within its supermarket. The supermarket concept with its unique nested stores has been very successful. With this strategy, Galleria has created a small community inside its supermarket. By doing so, Galleria provides not only a convenient one-stop shopping experience but also a sense of belonging for Korean immigrants who often experience cultural barriers in the mainstream society. For many Korean immigrants, the Galleria Supermarkets in the Toronto CMA is more than just a grocery store. The stores function as small cultural community centres by providing various cultural events and courses for Korean immigrants and the general public who are interested in learning about the Korean culture. Instead of developing a large ethnic shopping centre which can be found with bigger ethnic groups such as Chinese and Indian, Galleria Supermarket created a new business model that works better for smaller ethnic groups.

As Zhuang, Hernandez and Wang (2015) pointed out, mixed economy is more visible these days as major mainstream grocery chains enter into the profitable ethnic markets by providing ethnic oriented products and services, while some ethnic businesses expand their spectrum of customers to other ethnic groups and the mainstream society. Galleria Supermarket is a great example of the latter case as it has successfully expanded its business to the more 
lucrative Chinese and the mainstream customers who live nearby. A large number of Chinese immigrants in the Toronto CMA also shop at the Galleria Supermarket as the store provides diverse Asian groceries in a clean and spacious shopping environment.

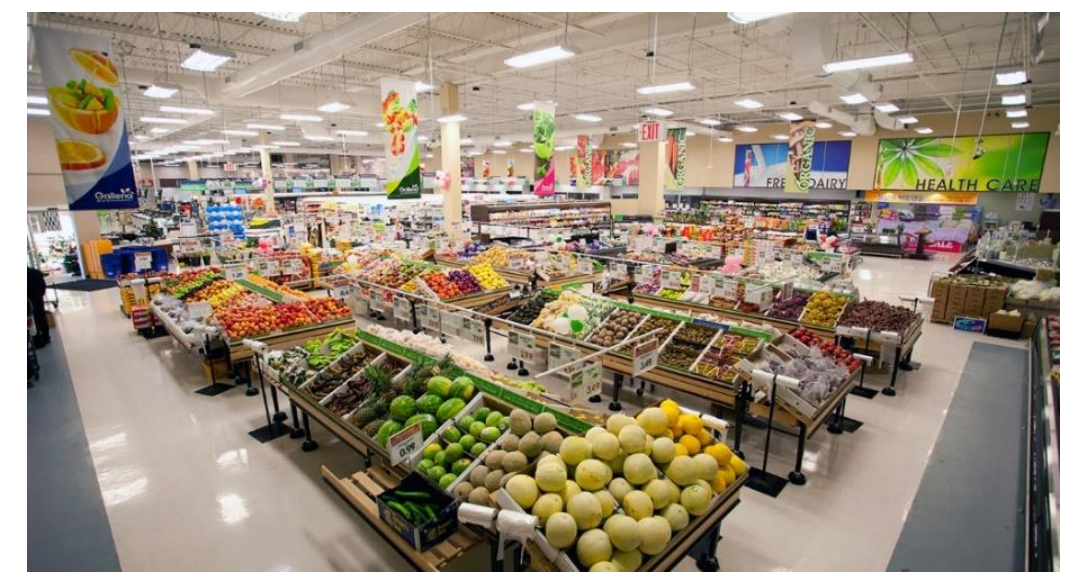

Figure 4.8: Inside of the Galleria Supermarket at York Mills and Don Mill (Source: Galleria Supermarket Website)

Galleria Supermarket is also a major Korean ethnic employer who provides employment opportunities mainly to Korean immigrants in the Toronto CMA with a diverse range of positions from cashiers, store managers to graphic/web designers and accounting professionals. While co-ethnic staffing is more controversial in the US, there have not been noticeable disputes or clashes reported in Canada in relation to the co-ethnic hiring practice of Korean ethnic businesses.

\subsection{2: H Mart}

H Mart is another big Korean Supermarket Chain in the Toronto CMA. Unlike the Galleria Supermarket, H Mart was originally founded in Queens, New York in the US. It started 
as a small corner store in 1982. Only more than one generation later, the supermarket chain now has 51 stores across the US and has become the biggest Asian grocery chain in the US (H Mart, 2016). The founder and CEO of H Mart, Mr. Il Yeon Kwon shares his belief that H Mart encourages fellow Korean immigrants to retain profound pride and dignity about the Korean culture by providing excellent Korean products and services (H Mart, 2016). With its headquarters in the U.S., H Mart has a division in Canada and the U.K. along with supply channels in Korea. H Mart's multinational network makes them the biggest transnational actor among the Korean supermarket chains. As a powerful multi-national Korean ethnic grocery chain, with its dominant force, $\mathrm{H}$ Mart has transformed Korean communities into transnational communities with their transnational capital and international supply channels by connecting Korean ethnic communities in each country with Korea and by supplying trendy Korean products.

Despite its tremendous success in the U.S., H Mart's co-ethnic hiring practice became controversial and got some local media attention in 2012. Some Black people and white people protested against its co-ethnic hiring practice outside of its Flushing store in New York. H Mart's payroll manager, Kenneth Noh, later made the following statement. "The company does not screen employees by race, but by their capabilities. The reason Korean employees dominate the chain's Flushing stores," he said, "is so they can cater to an incredibly large population of residents who don't speak English" (Chan, 2012). Another interesting fact about H Mart in conjunction with ethnic staffing is that they also employ quite a large number of Hispanic employees in the U.S. After cultural conflicts between Hispanic and Korean American employees caused by the lack of understanding of cultural differences at their store in Fairfax County, Virginia, the H Mart headquarters provided an intercultural training course, with 
translations in Spanish and raised wages for Hispanic workers to ease tensions between Hispanic and Korean American employees (Kang, 2007).

H Mart Canada has two divisions: One is H Mart British Columbia, the other is H Mart Ontario. H Mart's first Canadian store was opened in Coquitlam B.C. in 2003. It currently has 5 stores in the Greater Vancouver Area (H Mart Canada, 2016). H Mart Canada encountered a civil lawsuit against it in 2007 when three white tenants were ousted from the West Willow Shopping Mall that is owned by $\mathrm{H}$ Mart. They accused H Mart of practising racial discrimination against them (Advance, 2007). The three former tenants who had been long-term tenants of the mall claimed that new Korean owner wanted to turn the mall into an Asian only market, but their claim was dismissed by the B.C Human Rights Tribunal with the following statement: "In the end, I have concluded that the complainants' case is based on little more than conjecture based on what they read in the media and H-Mart's reputation as a 'Korean market,' as seen through the lens of their own unhappiness in being unable to maintain their businesses in the mall (Advance, 2007)."

The first H Mart in Ontario was opened in 2003 in Richmond Hill. It is a mega-sized store. Like Galleria Supermarket, H Mart in Richmond Hill also has various specialized retail stores inside the supermarket. Another noticeable feature of the branch is that the store is connected to another H Mart owned mega home shopping centre to provide convenient one-stop, home shopping experience. Unlike its mega-sized Richmond Hill store, two other H Mart stores are scaled down to mid-sized stores located in North York. H Mart Ontario also has one urban convenience store called M2M in North York. All of the H Mart stores in the Toronto CMA are located on Yonge Street between North York and Richmond Hill where the heavy Korean population is situated. Even though the H Mart in Richmond Hill has a marketing strategy for the 
Chinese neighbours by providing a Chinese language service, it is very clear that $\mathrm{H}$ Mart is more focused on gaining their market share within the Korean community in the Toronto CMA than becoming mainstream.

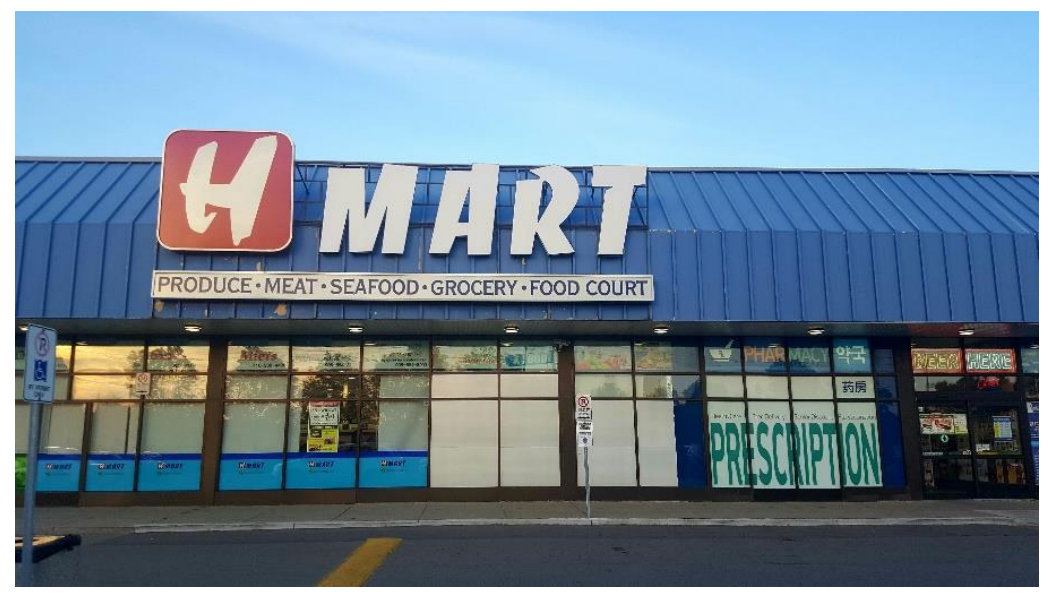

Figure 4.9: H Mart Richmond Hill, Ontario

While co-ethnic staffing is also dominant in the H Mart chains in Canada, complaints or protests against their co-ethnic hiring practice are unheard of in this country. Different public views on co-ethnic hiring between Canada and the U.S. is apparent, and the different response might be derived from the combination of different immigration policies, economic climates and compositions of ethnicity. In addition, with the strong mixed economy trend present in the Toronto CMA, major banks located in ethnic enclaves in the suburbs typically hire employees who speak their native languages and this kind of hiring practice is a strategically motivated business decision and their hiring practice is no different from the H Mart's co-ethnic hiring practice. 


\subsection{3: PAT Mart}

PAT Mart is the oldest Korean supermarket chain in the Toronto CMA with its wide coverage throughout the region. The first store opened in 1972 as a tiny corner store with limited ethnic Korean products. Currently, there are five PAT stores in the Toronto CMA. PAT is currently the only Korean supermarket chain that has a branch in Koreatown in the downtown cores of Toronto, Mississauga and Scarborough. While both Galleria and H Mart are focusing on attracting Korean immigrants living in North York, Thornhill and Richmond Hill where a heavy Korean population is found, PAT enjoys its monopoly in downtown Toronto, Mississauga and Scarborough. Unlike its other Korean competitors, PAT's flagship store is located in Koreatown in downtown Toronto. Thanks to its downtown location, the store attracts more diverse ethnic groups and mainstream customers than Galleria and H Mart. Due to its diverse customers, the employees at this location are fluent in English even though the majority of the employees are Korean. Co-ethnic staffing is one of the main characteristics of the Korean ethnic businesses. It seems that this hiring practice is based more on cultural understanding than the same language ability.

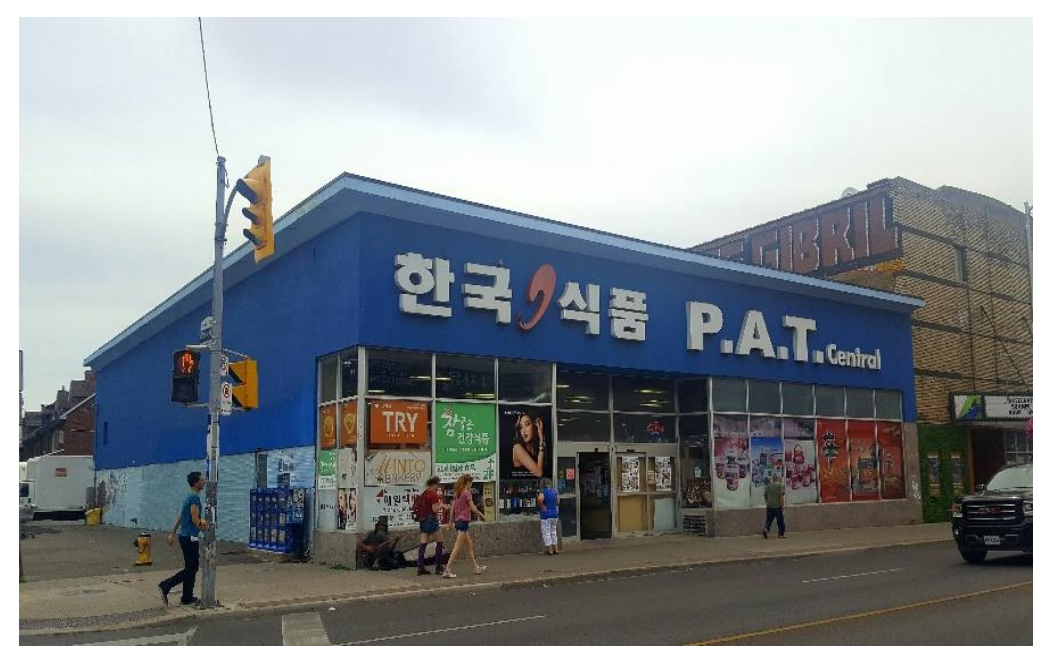

Figure 4.10: PAT Mart on Bloor St. West 
PAT not only imports ethnic products from Korea, but also produces ethnic food products locally. With its lengthy history, PAT created several local Korean food brands such as "Wang" (which means King in Korean) and "Surasang" (meaning King's dinner) (PAT, 2016). With its own local ethnic food products and distribution channels, PAT provides a diverse range of ethnic products. However, unlike Galleria, PAT does not run any cultural programs or classes.

As shown in Figure 4.11, PAT Mart's five stores are wide spread across the Toronto CMA and the locations of the stores are not aligned with the concentration of the Korean population. PAT Mart's business concept can be defined as an ethnic economy whereas that of H Mart in the Toronto CMA can be identified as a typical ethnic enclave economy; H Mart's all 5 stores are located on Yonge Street between North York, Thornhill and Richmond Hill where a Korean ethnic enclave is formed along with a heavy concentration of Korean ethnic businesses. H Mart's business strategy may be explained with its transnational status as a multi-national Korean ethnic grocery chain. While H Mart in the U.S. has broader target groups, H Mart in the Toronto CMA seems to focus on the Korean community and connects the Korean community with other Korean communities in Canada, the U.S. and the U.K. using their well-developed international supply channels and by doing so, they remain as the biggest global Korean grocery chain. Unlike H Mart and PAT Mart, Galleria Supermarket does not follow either concept, as one of their stores is located at the heart of a Korean ethnic enclave in the Toronto CMA and the other store is at York Mills and Don Mills which is a rather multiethnic neighbourhood. 


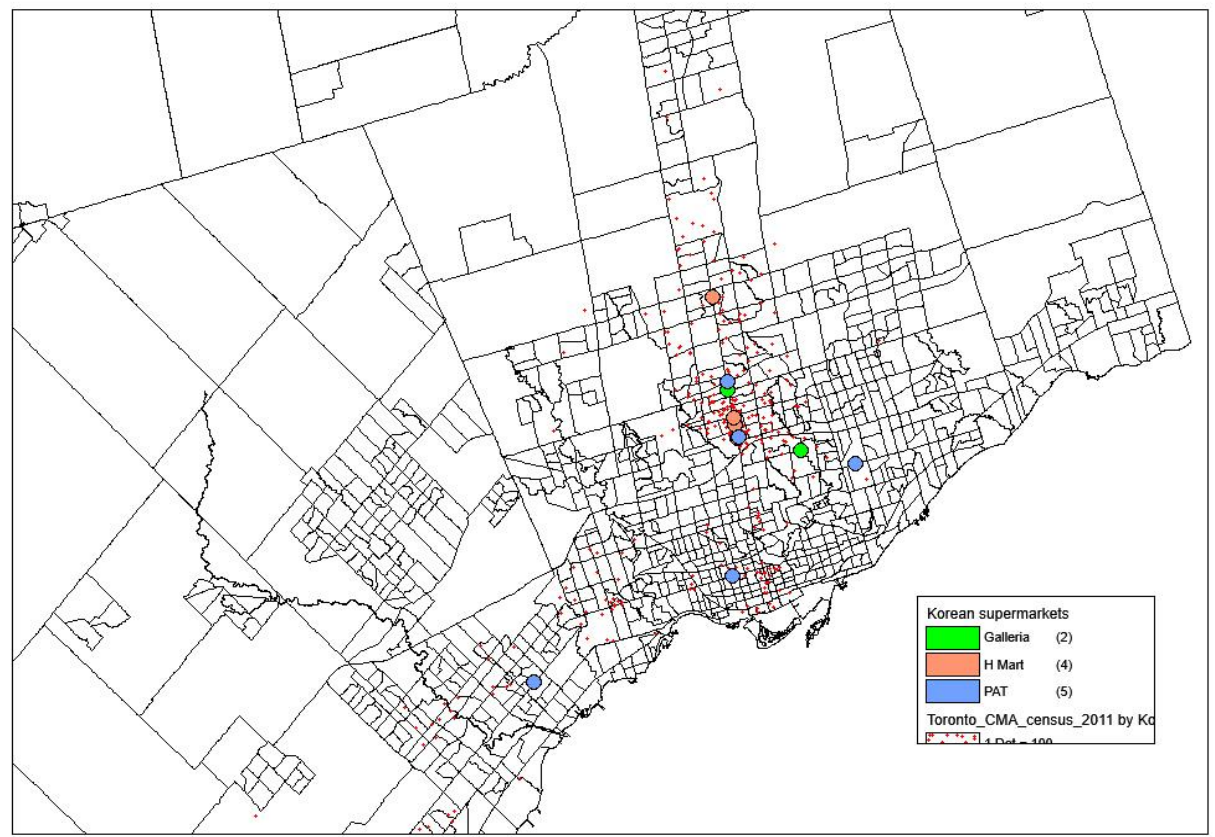

Figure 4.11: Korean Supermarkets in the Toronto CMA

(Source: Ontario Korean Business Directory, the Korea Times Daily)

These three major Korean supermarket chains in the Toronto CMA play major roles within the Korean community as major Korean ethnic employers by providing diverse employment opportunities for Korean immigrants and as active transnational actors connecting Korean immigrants with their home country and Korean communities in other countries by importing diverse Korean products and distributing through their international supply channels. For many Korean immigrants in the Toronto CMA, these supermarkets are more than stores where they buy Korean products. In particular, Galleria Supermarket provides various cultural and educational events and by doing so, it also provides "space" where they can feel a sense of belonging. For this matter, it can be said that Galleria Supermarket has established a symbolic reputation among Korean immigrants as a Korean community centre. 


\section{Chapter 5: Conclusion}

With Canada's Points System, a large number of Korean immigrants were selected to Canada in the 1990s, who mainly settled in the Toronto and Vancouver CMAs. These skilled immigrants were expected to integrate into the Canadian labour market faster than the earlier cohorts because they came with superior human capital (such as high education and professional experience) compared with those who entered Canada mainly under the family sponsorship class. However, their limited English/French language ability and the systemic barriers blocked them from participating in the Canadian labour market and forced them to either pursue employment opportunities in the local Korean ethnic economy or become entrepreneurs or selfemployed, resulting in an exceptionally high self-employment rate. While Koreans remain among the lowest income earners, their self-employment income is much higher than most other immigrant groups. The self-employment income data supports Couton's (2014) argument that a high self-employment rate among Koreans is an outcome of a defensive and survival strategy against systemic barriers as they financially perform better as self-employed rather than employees. A combination of active transnational activities among Korean immigrants (including "goose families" and a large number of international students who typically have strong transnational ties between home country and Canada) and a high level of entrepreneurship among Koreans accelerated the formation of Korean ethnic enclave in the Toronto CMA and made the Korean community more transnational. As discussed in the paper, it is reasonable to conclude that Koreans have formed an "ethnoburb" in the North York and Thornhill area along the Yonge street corridor. There is a heavy concentration of a Korean population in the area with a Korean ethnic business centre at Yonge and Finch along with the presence of diverse Korean businesses and various educational, social and economic institutions in the area. This research 
concludes that the formation of a Korean "ethnoburb" in the North York and Thornhill area is due to the combination of the following: 1) a large number of Korean economic class immigrants (such as skilled workers, entrepreneurs and investors) with human and financial capital, which generated diverse Korean businesses, 2) difficulties of integrating into the Canadian labour market due to various systemic barriers and their limited official language ability, which forced many immigrants to stay in the Korean ethnic businesses and 3) active transnational activities among Korean immigrants and a large volume of Korean international students in the Toronto CMA, and 4) the preference to live in the Korean community for convenience and a sense of belonging. Consequently, these four factors are also the main causes of the high self-employment rate among Korean immigrants in Canada which are discussed in the paper with theories of Social Exclusion, Ethnic Facilitation combined with Labour Market Segmentation, Ethnic Entrepreneurship and Transnationalism.

Canada's Points System selected and brought Korean immigrants with diverse professional backgrounds which led to the diversification of Korean businesses and the formation of self-sustaining Korean ethnic economy in the Toronto CMA. It seems that the Korean ethnic economy has developed its niche market in certain businesses such as restaurants, travel agencies and private education services, but these businesses have rapidly proliferated through "the training system". As a result, their already disadvantaged economic opportunities and performance became worse in many cases, as explained in the paper. However, in more recent years, some Korean ethnic businesses (such as Korean Supermarket chains) have developed more competitive advantages by developing transnational strategies and adopting a mixed economy concept. The success of these Korean supermarket chains could be a good role model for other Korean ethnic businesses by adapting to fast changing markets in the world of 
globalization and by broadening the spectrum of their consumers from the Korean community to more diverse ethnic groups and even to the mainstream market while maintaining their ethnic identity. In addition, in order for the Korean ethnic economy and Korean community in general to maintain its size and continue to grow, it is crucial to have the continuous inflow of Korean temporary residents such as international students and visitors who act not only as consumers of Korean ethnic economy but also as major transnational actors by connecting Korea and the Korean community in the Toronto CMA.

Families with young children or teenagers are the main immigrant group among Koreans. The main motive for immigrating to Canada for these families was better and less competitive educational environment in Canada for their children. Parents tend to sacrifice their way of life for their children's education and future in Canada by working long hours at their retail stores or being separated in two countries. The Korean "goose families" and a large number of Korean international students in Canada play major roles in transforming the Korean community into one of the most transnational communities in the Toronto CMA as they are actively involved in various transnational activities on a daily basis as their family members live in both countries. However, "goose families" and the lack of communication between family members due to long working hours have created various family issues which often lead to high levels of stress or in worse cases physical violence between family members. While there are settlement services available in the Korean language in the North York and Thornhill areas, there is no specific support system to help these families to maintain their well-being. It is recommended that more specialized support programs be implemented by the local settlement service agencies. 
With the neoliberal approach, the previous federal government's immigration policy was focusing on the official language proficiency and pre-arranged employment in Canada to maximize new-comers' fast economic integration without providing adequate settlement services for new immigrants such as the official language training, job training, or accreditation of foreign education. It is predicted that fewer Koreans will be admitted as immigrants in the future and that more racialized immigrants including Koreans will be marginalized with the current neoliberal immigration policy that emphasizes English/French ability and Canadian work experience and credentials because of the lack of settlement services. Therefore, it would be beneficial for the Canadian government in the long-term to be proactive by implementing extensive settlement services such as language and job training courses, foreign credential bridging programs and government assisted entrepreneurship programs. The Trudeau government should expand settlement services for newcomers and create a new policy to dismantle various systemic barriers against racialized immigrants and newcomers for their faster socio-economic integration. It is also recommended that the settlement services provide more extensive services in the Korean language to assist Korean newcomers and other immigrants who are not fluent in the official languages while continuously providing the official language training.

As stated previously, this research has used limited data to identify settlement patterns of Korean immigrants in the Toronto CMA. To analyze the settlement patterns in greater detail, a broader range of data should be used in future research. While some research papers are available for the Toronto CMA and Vancouver CMA, little research has been done for Korean immigrants in different cities in Canada. With various provincial nominee programs available, more and more Korean immigrants settle in different provinces such as Alberta, Manitoba and 
Saskatchewan. For this reason, future studies in these provinces can be useful to understand new patterns of Korean immigrants in Canada. 


\section{References}

Advance, L. (2007). Claim of discrimination against whites dismissed. Retrieved from: http://www.canada.com/story_print.html?id=f59b9bd2-88cc-4a28-8722$\underline{\mathrm{b} 87 \mathrm{ab} 4422703 \& \text { sponsor }}=$

Bai, D. (2006). Koreans. Historica Canada revised by D. Baker and J. Tattrie. Retrieved from: http://www.thecanadianencyclopedia.ca/en/article/koreans/

Basch, L.G., Glick-Schiller, N. and Blanc-Szanton, C. (1994). Nations Unbound: Transnational Projects, Post-colonial Predicaments, and Deterritorialzed Nation-States. Langhorne, PA: Gordon and Breach.

Breton, R. (2003). Social Capital and the Civic Participation of Immigrants and Members of Ethno-Cultural Groups. Paper resented at the conference "Opportunity and Challenge of Diversity: A Role for Social Capital?" Policy Research Initiative, Government of Canada, November 24-25, Montreal

Boyd, M. and Alboim, N. (2012). Managing International Migration: The Canadian Case. Dan Rodriguez-Garcia, ed. Managing Immigration and Diversity in Canada. Montreal \& Kingston: McGill-Queen's University Press, 2012.

Chan, E. and Fong, E. (2012). Korean self-employment in Canada. Korean immigrants in Canada Perspectives on Migration, Integration, and the Family edited by Noh, S., Kim, A. \& Noh, M. Toronto: University of Toronto Press

Chan, M. (2012). Protesters call H-Mart's hiring racist, QNS. October 24, 2012: Retried from: http://qns.com/story/2012/10/24/protesters-call-h-marts-hiring-racist/\#comment-303161

Chow, S. (2012). The Korean "Goose Family" Phenomena: Educational Migrants, the Center for Global Prosperity Hudson Institute. Retrieved from: http://globalprosperity.wordpress.com/2012/08/22/the-korean-goose-family-phenomenaeducational-migrants/

Citizenship and Immigration Canada. (2011). Landed Immigrant Data System, 1980-2010

Couton, P. (2014). Ethnocultural Community Organizations and Immigrant Integration in Canada, IRPP Study.

Diminescu, D. (2008). The connected migrant: An epistemological manifesto. Social Science Information 47(4) pp. 565-579

Galabuzi, G. (2006). Canada's Economic Apartheid: The Social Exclusion of Racialized Groups in Canada's New Century. Toronto: Canadian Scholar's Press.

Galleria Supermarket Website (2016): http://www.galleriasupermarket.com/pagecompany/gnk_introduction.aspx 
Ghosh, S. and Garrison R. (2015) Ethnic Retailing in Bauder, H. \& Shileds, J (Eds.). Immigrant Experiences in North America: Understanding Settlement and Integration. Toronto: Canadian Scholars' Press. pp. 388-408

Guarnizo, L. Landolt, P. and Portes, A. (1999). The study of transnationalism: pitfalls and promise of an emergent research field. Ethnic and Racial Studies. pp. 217-237, DOI: $10.1080 / 014198799329468$

Han, J. and Ibbott, P. (2005). Korean Migration to North America: Some Prices That Matter. Canadian Studies in Population, Vol. 32.2, 2005, pp. 155-176

Hiebert, D. (2002). Economic associations of immigrant self-employment in Canada. International Journal of Entrepreneurial Behaviour \& Research, Vol. 8 No. 1/2, 2002. pp. 93-112

H Mart Website (2016): http://www.hmart.com/about-us/history/

H Mart Canada Website (2016): http://hmartca.com/hmart/

Hou, F., and Wang, S. (2011). Immigrants in Self-Employment. Perspectives on Labour and Income 23 (3), cat. No. 75-001-XIE. Ottawa: Statistics Canada.

Huang, S. and Yeoh, B. (2005). Transnational Families and their Children's Education: China's 'Study Mothers' in Singapre. Global Networks 5 (4) pp. 379-400

Kang, C. (2007). Koreans, Hispanic Work for Harmony, Washington Post. October 7, 2007: http://www.washingtonpost.com/wpdyn/content/article/2007/10/06/AR2007100601389.h $\underline{\mathrm{tml}}$

Kelly, N. and Trebilcock, M. (2010). 'Immigration Policy, 1963-1976'. The Making of the Mosaic: A History of Canadian Immigration. Policy. Second Edition. Toronto: University of Toronto Press.

Kelly, P. (2003). Canadian-Asian transnationalism. Toronto: The Canadian Geographer, 47(3) pp. 209-219

Korea Times Daily. (2016). Ontario and the Greater Toronto Area Business Directory. Retrieved from: http://yellowpage.koreatimes.net/

Kwak, M. (2012). International Student Experience of Migration and Consuming Canadian Education. Korean immigrants in Canada Perspectives on Migration, Integration, and the Family edited by Noh, S., Kim, A. \& Noh, M. Toronto: University of Toronto Press

Li, W. (1997). Spatial transformation of an urban ethnic community from Chinatown to Chinese ethnoburb in Los Angeles. PhD thesis, University of Southern California. Los Angeles.

Li, W. (1998). Anatomy of a New Ethnic Settlement: The Chinese Ethnoburb in Los Angeles, Urban Studies, Vol.35, No3, pp. 479-501

Light, I. and Bonacich, E. (1988). Ethnic Entrepreneurs: Koreans in Los Angeles, 1965-1983, University of California Press, Berkeley, CA. 
Light, I. and Gold, S. J. (2000). The Ethnic Economy since Weber. Ethnic Economies. San Diego: Academic Press.

Lindsay, C. (2007). Profiles of Ethnic Communities in Canada: The Korean Community in Canada (2001). Aboriginal Statistics Division cat. no. 89-621-XIE, no. 14. Ottawa: Statistics Canada.

Massey, D. (1985). The Settlment Process among Mexican Migrants to the United States: New Methods and Findings. In D. Levine, K. Hill, and R. Warren (eds.) Immigration Statistics: A Story of Neglect, pp. 255-292. Washington, DC: National Academy Press.

Mata, F. and Pendakur, R. (1999). Where do immigrants work? Tracking industrial location propensities of 1960s immigrants. Research on Immigration and Integration in the Metropolis. Working Paper Series. Vancouver Centre of Excellence. Retrieved from: http://mbc.metropolis.net/assets/uploads/files/wp/1999/WP99-13.pdf

Ministry of Foreign Affairs, Republic of Korea. (2013). North America: Canada.

Murdie, R. and Teixeira, C. (2003). Towards a Comfortable Neibourhood and Appropriate Housing: Immigrant Experience in Toronto. The World in a City edited by Paul Anisef and Michael Lanphier. Toronto: University of Toronto Press

Panagokos, A. and Horst, H. (2006). Return to Cyberia: Technology and the social worlds of transnational migrants. Global networks 6(2) pp. 109-124

Park, J. (2012). A Demographic Profile of Koreans in Canada. Korean Immigrants in Canada: Perspectives on Migration, Integration, and the Family, edited by S. Noh, A.H. Kim, and M.S. Noh, 19-34. Toronto: University of Toronto Press.

PAT Mart Website (2016): http://www.patmart.net/pat/

Portes, A. (1997). Immigration Theory for a New Century: Some Problems and Opportunities. International Migration Review, Vol. 31, No. 4, Sepcial Issue: Immigrant Adaptation and Native-Born Responses in the Making of Americans (Winter, 1997). pp. 799-825

Preston, V., Kobayashi, A. and Siemiatycki, M. (2006). Transnational Urbanism: Toronto at a Crossroads, Transnational Identities and Practices in Canada. Vancouver, BC: The University British Columbia. pp. 91-110

Salaff, J., Greve, A., Wong, S. and Ping, L. (2003). Ethnic Entrepreneurship, Social Networks, and the Enclave. Approaching Transnationalism: Transnational Societies, Multicultural Contacts, and Imagining of Home. edited by Yeoh, B., Kiong, T. \& Charney, M. Boston: Kluwer Academic Publishers.

Schellenberg,G. and Maheux, H.(2007). Immigrants' perspectives on their first four years in Canada: Highlights from three waves of the Longitudinal Survey of Immigrants to Canada. Canadian Social Trends, Special Edition. Statistics Canada Catalogue no. 11008-XWE. (accessed February 5, 2010). Section two: Difficulties encountered. Retrieved from: http://www.statcan.gc.ca/pub/11-008-x/2007000/9627-eng.htm\#10 
Siemiatycki, M. and Matheson, A. (2005). Suburban Success: Immigrant and minority electoral gains in suburban Toronto. Canadian Issues, summer, pp. 69-72

Simmons, A. (2010). Immigration and Canada: Global and Transnational Perspectives. Critical Issues in Contemporary Sociology, under the direction of Vic Satzewich. Toronto: Canadian Scholars' Press Inc.

Statistics Canada. (2006). Census 2006. Average Employment Income by Racialized Group

Statistics Canada. (2007). The Korean Community in Canada. Retrieved from: http://www.statcan.gc.ca/pub/89-621-x/89-621-x2007014-eng.htm

Statistics Canada. (2011). 2011 National Household Survey: Immigration, place of birth, citizenship, ethnic origin, visible minorities, language and relgion. Retrieved from: http://www.statcan.gc.ca/daily-quotidien/130508/dq130508b-eng.htm

Statistics Canada. (2015). Tax Data in Landed Immigrant Data System

Trimble, L. and Treiberg, N. (2011). Content Analysis. In Archer, K. and Berdahl, L. (Eds.), Explorations: Conducting Empirical Research in Canadian Political Science. Don Mills, Ontario: Oxford University Press

Vertovec, S. (1999). Conceiving and researching transnationalism, Ethnic and Racial Studies 22(2): 445-62. in Castles, S. 2000. International Conference on Transnational Communities in the Asia Pacific Region: Comparative Perspectives, Singapore 7-8 August, 2000

Waldinger, R., Aldrich, H., Ward, R. and associates (1990). Ethnic Entrepreneurs: Immigrant Business in Industrial Societies, Sage, Newbury Park, CA.

Waldinger, R. (2013). Immigrant transnationalism. Current Sociology Review. Sage. 61 pp. 5-6,

Wang, S. and Du, P. (2012). Diversity of Asian Immigrants and Their Roles in the Making of Multicultural Cities in Canada.

Wang, S., Hii, R., Jhong, J. and Du P. (2013). Recent Trends in Ethnic Chinese Retailing in Metropolitan Toronto. International Journal of Applied Geospatial Research 3(4) pp. 4966

Wang, S. and Jhong J. (2013). Delineating Ethnoburbs in Metropolitan Toronto, CERIS Working Paper Series No. 100.

Wong, L. and Satzewich, V. (2006). The Meaning and Significance of Transnationalism, Transnational Identities and Practices in Canada. Vancouver, BC: The University British Columbia. pp. 1-15

Yoon, I. (2006). Understanding the Korean Diaspora from Comparative Perspectives, Transformation \& Prospect toward Multiethnic, Multiracial \& Multicultural Society: Enhancing Intercultural Communication, Asia Culture Forum. P. 17. Retrieved from: http://www.cct.go.kr/data/acf2006/multi/multi_0201_In-Jin\%20Yoon.pdf 
Yoon, I. (2012). The Korean Diaspora from Global Perspectives. Korean immigrants in Canada Perspectives on Migration, Integration, and the Family edited by Noh, S., Kim, A. \& Noh, M. Toronto: University of Toronto Press

Zhou, M. (2004). Revisiting Ethnic Entrepreneurship: Convergencies, Controversies, and Conceptual Advancements. International Migration Review 38 (3) pp. 1040-1074

Zhuang, Z., Hernandez, T. and Wang, S. (2015). Ethnic Retailing in Bauder, H. \& Shileds, J (Eds.). Immigrant Experiences in North America: Understanding Settlement and Integration. Toronto: Canadian Scholars' Press. pp. 223-247. 